Engineering

Manuscript Number: ECOLENG-D-15-01350R1

Title: Sources of Iron (Fe) and Factors Regulating the Development of Flocculate from Fe-Oxidizing Bacteria in Regenerative streamwater Conveyance Structures

Article Type: Research Paper

Keywords: Best Management Practice (BMP), Coastal Plain, Flocculate, Iron-Oxidizing Bacteria (FeOB), Piedmont, Regenerative Stormwater Conveyance (RSC), Stream Restoration

Corresponding Author: Prof. Michael Williams, PH.D.

Corresponding Author's Institution: Smithsonian Environmental Research Center

First Author: Michael R Williams, Ph.D.

Order of Authors: Michael R Williams, Ph.D.; Barret M Wessel, B.S.; Solange Filoso, $\mathrm{Ph} . \mathrm{D}$.

Abstract: Regenerative streamwater conveyances (RSCs) are a relatively new stream restoration best management practice (BMP) being extensively implemented in degraded perennial streams and stormwater drainages throughout the mid-Atlantic. Although there is currently a great deal of interest in this type of $\mathrm{BMP}$ as a means of reducing nutrient and sediment export from disturbed catchments, little is known of its pollutant reduction capabilities and whether there are unintended ecological consequences associated with these structures. For example, dense accumulations of flocculate from iron-oxidizing bacteria (FeoB) have been observed at numerous RSC sites, yet it is unknown whether this flocculate is predominately natural, a consequence of leached iron (Fe) from the materials used in the RSC construction, or because of mobilized Fe from catchment soils influenced by higher groundwater levels that may occur after construction. We analyzed Fe and other solute concentrations in groundwater and perennial streams at RSC and control sites located in the Coastal Plain and Piedmont physiographic provinces of MD and DC, and conducted leaching experiments using RSC soils and construction materials. Iron flocculate from FeOB in RSCs is commonly localized and depends on several factors including a source of reduced Fe, the availability of dissolved organic carbon (DOC) responsible for leaching this Fe, and specific hydrological (i.e., low flow) and physical (i.e., warmer temperatures) conditions. Sources of reduced Fe are derived from both construction materials and catchment soils, which leach Fe in the presence of DOC originating from natural organic matter (OM) deposits and OM incorporated into the RSCs (i.e., wood chips, leaves, logs). Using construction materials that have relatively low \% Fe content in areas strongly influenced by OM will likely decrease the spatial and temporal presence of dense mats of Fe flocculate thereby improving RSC habitat, performance and sustainability. 


\section{Sources of Iron (Fe) and Factors Regulating the Development of Flocculate from Fe-Oxidizing Bacteria in Regenerative Streamwater Conveyance Structures}

Michael R. Williams ${ }^{*}+$, Barret M. Wessel $\neq$, and Solange Filoso $\dagger$

$\dagger$ University of Maryland Center for Environmental Science, Chesapeake Biological Laboratory, Solomons, MD 20688

† University of Maryland, Department of Environmental Science and Technology, College Park, MD 20742

*Current: Smithsonian Environmental Research Center, P.O. Box 28, 647 Contees Wharf Road, Edgewater, MD 21037-0028; williamsmi@si.edu 


\section{ABSTRACT (291 words)}

Regenerative streamwater conveyances (RSCs) are a relatively new stream restoration best management practice (BMP) being extensively implemented in degraded perennial streams and stormwater drainages throughout the mid-Atlantic. Although there is currently a great deal of interest in this type of BMP as a means of reducing nutrient and sediment export from disturbed catchments, little is known of its pollutant reduction capabilities and whether there are unintended ecological consequences associated with these structures. For example, dense accumulations of flocculate from iron-oxidizing bacteria $(\mathrm{FeOB})$ have been observed at numerous RSC sites, yet it is unknown whether this flocculate is predominately natural, a consequence of leached iron $(\mathrm{Fe})$ from the materials used in the RSC construction, or because of mobilized Fe from catchment soils influenced by higher groundwater levels that may occur after construction. We analyzed Fe and other solute concentrations in groundwater and perennial streams at RSC and control sites located in the Coastal Plain and Piedmont physiographic provinces of MD and DC, and conducted leaching experiments using RSC soils and construction materials. Iron flocculate from FeOB in RSCs is commonly localized and depends on several factors including a source of reduced Fe, the availability of dissolved organic carbon (DOC) responsible for leaching this Fe, and specific hydrological (i.e., low flow) and physical (i.e., warmer temperatures) conditions. Sources of reduced Fe are derived from both construction materials and catchment soils, which leach Fe in the presence of DOC originating from natural organic matter (OM) deposits and OM incorporated into the RSCs (i.e., wood chips, leaves, logs). Using construction materials that have relatively low \% Fe content in areas strongly influenced by OM will likely decrease the spatial and temporal presence of dense mats of Fe flocculate thereby improving RSC habitat, performance and sustainability. 


\section{KEYWORDS}

25 Best Management Practice (BMP), Coastal Plain, Flocculate, Iron-Oxidizing Bacteria (FeOB),

26 Piedmont, Regenerative Streamwater Conveyance (RSC), Stream Restoration

27

28

\section{INTRODUCTION}

Natural disturbances and landscape development in watersheds commonly degrade streams and the ecosystem services they provide (Doyle et al. 2000, Sweeney et al. 2004, Grimm et al. 2005, Meyer et al. 2005, Poff and Zimmerman 2010, Vietz et al. 2012). The specific mechanisms that lead to the degradation of streams and the loss of ecosystem services vary according to landscape settings and types of stressors (Walsh et al. 2005, Wenger et al. 2009), and the extent of the degradation is often reflected in streams because water quality integrates various biogeochemical processes affected by natural and human disturbances (Likens et al. 1970, Likens and Bormann 1995, Williams and Melack 1997a \& b, Williams et al. 2005). Stream restoration and stormwater best management practices (BMPs) are increasingly implemented with the expectation that they will restore hydrochemical regimes and improve water quality, habitat, and biodiversity (FISRWG 1998). Because only modest improvements with regard to water quality and sediment transport commonly occur with these types of implementations (Selvakumar et al. 2010, Filoso and Palmer 2011, Palmer et al. 2014), environmental engineers have attempted to improve nutrient and sediment reduction efficiencies (i.e., their ability to reduce these constituents in stormwater runoff) by creating novel designs, such as stream-wetland complexes (Filoso et al. 2015) and regenerative streamwater (or stormwater) conveyances (RSCs). In particular, RSCs implemented in headwater channels are designed to reduce erosion (Brown et al. 2010), increase stormwater retention and the capacity to 
48 trap and retain suspended materials, and increase rates of biogeochemical processes such as denitrification (Brown 2000).

Despite RSCs having been implemented throughout Maryland and Washington DC for over a decade, there is a paucity of information available concerning their nutrient and sediment reduction capabilities and sustainability (Palmer et al. 2014). It has been argued that RSCs improve water quality (Berg and Underwood 2007; Bowen 2012; Brown et al. 2010), but peerreviewed studies addressing their performance are lacking. Moreover, there may be deleterious ecological effects associated with RSCs implemented as either reconfigured streams or stormwater BMPs. For example, it is unknown whether the occurrence of large quantities of iron (Fe) flocculate sometimes observed within these structures is natural or an artifact of the structure itself, and whether this flocculate is negatively impacting water quality or stream habitat. Although Fe flocculate in streams is commonly associated with acid mine drainage that has high Fe concentrations and low $\mathrm{pH}$, flocculate is also found in streams with relatively low $\mathrm{Fe}$ concentrations (<1 mg/L) and circumneutral pH (Hayer et al. 2013, Fleming et al. 2014). Possible deleterious ecological impacts of dense Fe flocculate include a reduction of benthic substrate that can be used by aquatic macroinvertebrates (Wellnitz et al. 1994), decreases in water exchange due to plugging of sediment pores (Ghiorse 1986), changes in the redox potential of stream sediments, and others (Rasmussen and Lindegaard 1988, Gerhardt 1992).

Fe flocculation is driven by Fe oxidation and reduction, and is often mediated by several types of bacteria (Emerson et al. 2010, Melton et al. 2014). Anoxic conditions with ample mineral Fe and labile DOC create an environment where Fe-respiring microbes (FeRM) utilize alternative electron acceptors thereby causing the reduction and dissolution of $\mathrm{Fe}$ (i.e., $\mathrm{Fe}$ (III) to $\mathrm{Fe}(\mathrm{II})$ ); manganese (Mn) is affected similarly (i.e., Mn(IV) to Mn(II); Lovely 1986). Some 
71 fraction of these reduced metals will commonly persist in solution as cations (Brannon et al.

72 1984). The role of DOC in this process is poorly understood, but certain bacteria use humics and

73 quinones as electron acceptors and these chemicals, once reduced, abiotically reduce Fe (Lovley

74 2000). This process may allow FeRM to access oxidizing agents that would otherwise be

75 occluded, and some DOC in solution may be able to chelate Fe(III) thereby increasing its

76 availability to FeRM (Lovley 2000).

77 Groundwater can become enriched with reduced Fe through a combination of these

78 processes. In areas where such Fe-rich groundwater percolates to the surface, some is oxidized

79 and abiotically precipitates as Fe hydroxides at circumneutral $\mathrm{pH}$, or is oxidized by Fe-oxidizing

80 bacteria $(\mathrm{FeOB})$ as part of their metabolism (Emerson and Revsbech 1994a, Johnson et al. 2014).

81 Where flocculate develops around these groundwater seeps, as much as $80 \%$ of the Fe oxidation

82 can be microbially mediated (Emerson 2000, Emerson and Revsbech 1994b).

83 Fe flocculation is a natural process that can be seen in many streams throughout the Mid-

84 Atlantic region (Robbins 1998, Robbins and Norden 1994) and elsewhere (Emerson 1994a \& b,

85 Schieber and Glamoclija 2007). Maryland is underlain by widespread Fe deposits (Singewald

86 1911) that influence groundwater chemistry (Robbins and Norden 1994). Nevertheless, some

87 construction materials used in RSCs, such as ironstone (i.e., Bog Iron), have high Fe content, and

88 organic matter $(\mathrm{OM})$ incorporated into RSC structures (commonly about $<20 \%$ by volume,

89 Bowen 2012) can be a significant source of dissolved organic carbon (DOC). Degradable OM is

90 broken down aerobically and anaerobically to produce low molecular weight sugars and organic

91 acids such as acetate that are common substrates for Fe-reduction (Lovley 2000). Therefore,

92 while Fe flocculate observed at RSC sites could be a natural occurrence at some streams, it is

93 possible that mat formation is enhanced by 1) elevated Fe concentrations in stream water 
94 influenced by construction materials, 2) the mobilization of Fe from catchment soils outside of

95 RSC construction areas that become inundated by elevated groundwater tables or 3) a

96 combination of the two.

97 Herein we determine the factors responsible for regulating the development of Fe flocculate 98 at RSC sites in streams of the Coastal Plain and Piedmont physiographic provinces of MD and

99 DC. We identify the sources of Fe potentially contributing to the development of Fe flocculate 100 by conducting total Fe analyses and leaching experiments on soils extracted from our study sites 101 and construction materials used in RSCs. Moreover, we evaluate differences in the 102 hydrochemistry of riparian and hyporheic groundwater, and stream water among RSC and 103 degraded control sites. The OM content and physical habitat metrics of the study sites are also 104 compared. Pre- and post-RSC construction Fe and DOC concentrations in groundwater wells 105 and stream water (baseflow and stormflow) at one intensively monitored site are examined. 106 These data were used to determine whether RSCs commonly have more persistent and dense 107 mats of flocculate from FeOB compared to control sites and, if so, whether Fe leached from 108 construction materials or mobilized from elevated groundwater tables in catchment soils are 109 factors contributing to flocculate development. The ecological implications of dense flocculate 110 in RSCs and potential remedial measures are discussed. 


3

\section{STUDY SITES}

The RSC and control sites (11 total) monitored in this study are located in Washington DC, and Montgomery and Anne Arundel Counties of MD (Figure 1). All of the Anne Arundel sites and 2 DC sites are located in the Coastal Plain, whereas the other DC sites and the Montgomery County site are in the Piedmont. Site names and abbreviations are: Spring Valley (SV - control), Linnean Ave. (LA - Figure 2), Milkhouse Run (MR), Bingham Ford (BF), and Garrett Park (GP) in the Piedmont (www.montgomeryparks.org/pdd/documents/Waverly-

Schuylkill\%20award\%20012610\%20final.pdf), and Saltworks Creek Sand Seepage (SS), Saltworks Creek End-of-Pipe (EP), and Aurora Ave. (AR) in the Coastal Plain. Control sites in the Coastal Plain are located at $33^{\text {rd }}$ St. SE (33), Texas Ave. (TA), and a creek at the confluence of the AR site (Aurora Control - AC).

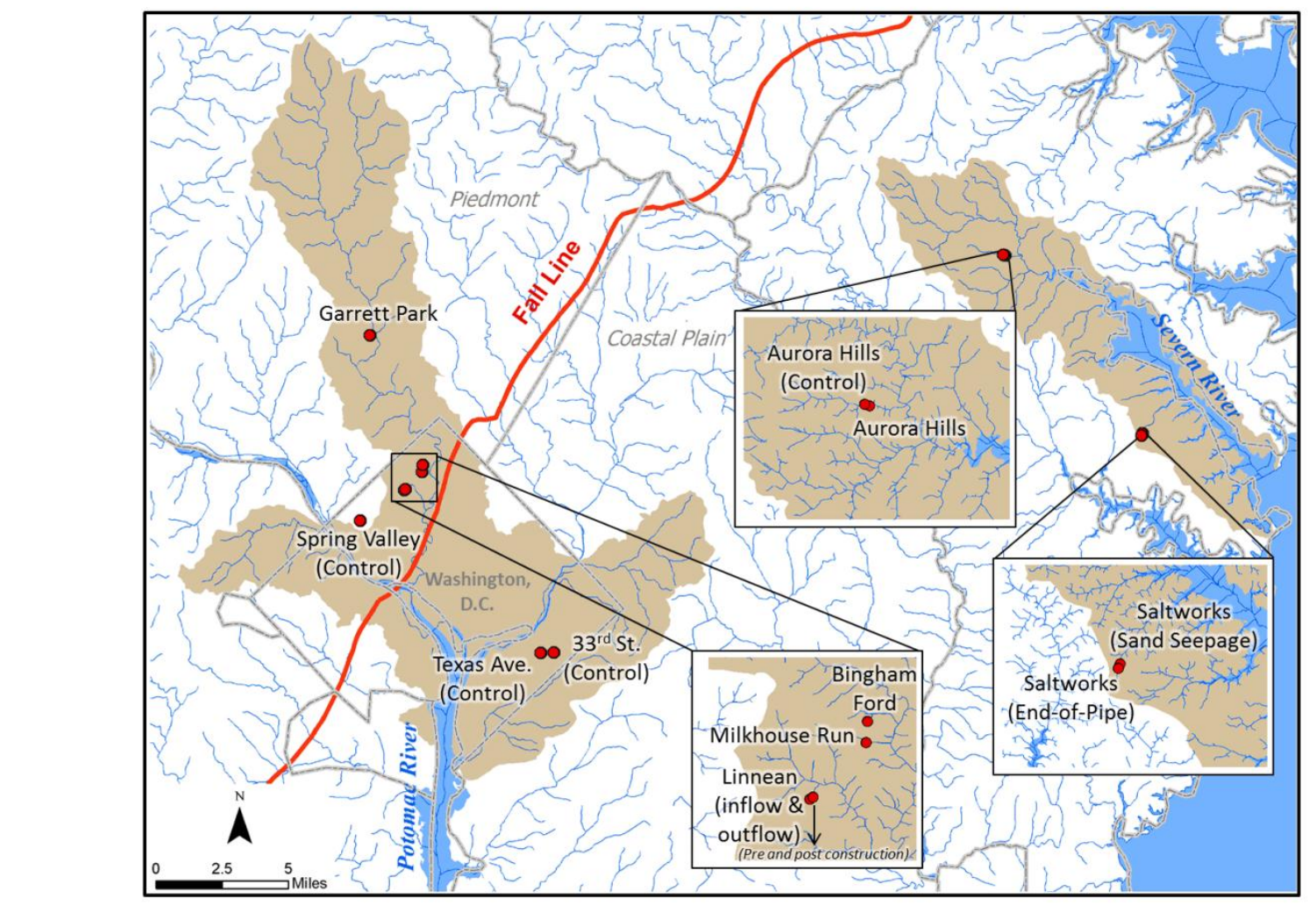

Figure 1: Map of study sites located in the Coastal Plain and Piedmont physiographic provinces of MD and DC. 
that used granite, all other

RSC sites were constructed

139 ironstone substrates (i.e.,

140 small and large conglomerate

141 and sandstone boulders and

142 loose sand) to create weirs at

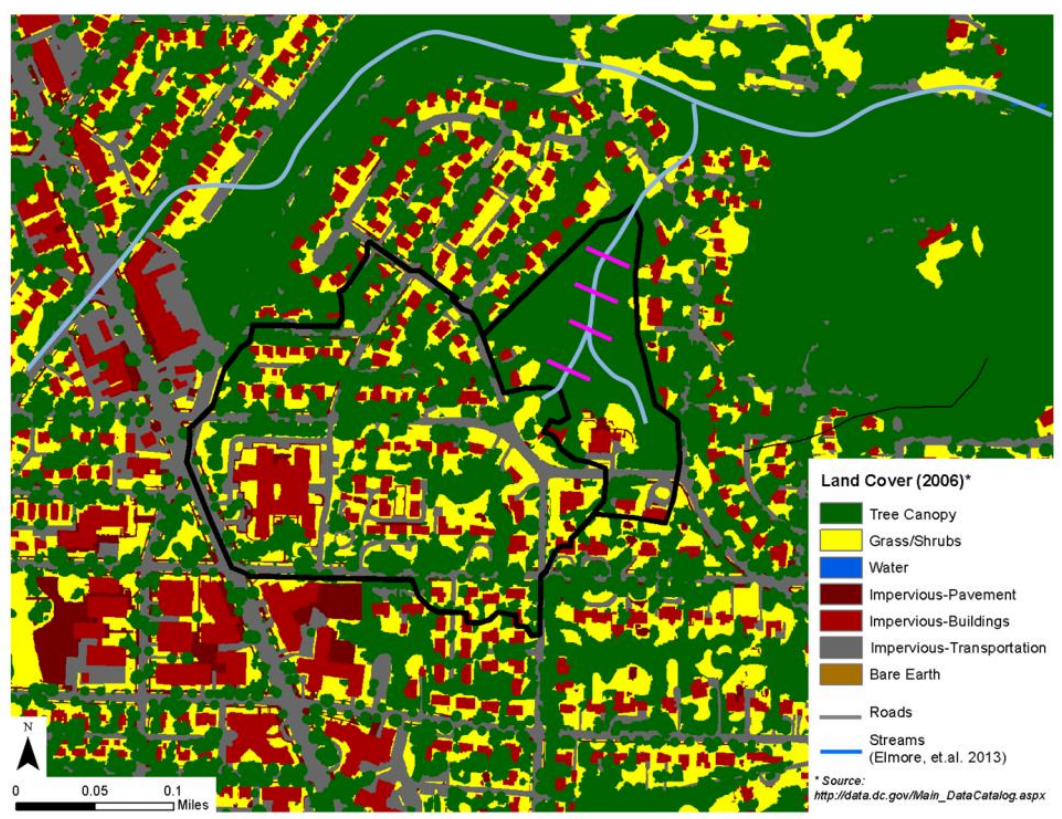

143 the downstream end of each

144 ponding basin (Table 1).

Figure 2: Land use and catchment delineation for Linnean Ave. (LA); well transects are shown as perpendicular lines to the stream reach.

Table 1: Site characteristics obtained from the Natural Resources Conservation Service (NRCS). A more comprehensive list of soils and other attributes of the study sites can be obtained by entering the latitude and longitude in the NRCS soil survey link (http://websoilsurvey.nrcs.usda.gov/app/WebSoilSurvey.aspx). The incidence of flocculate is based on a subjective assessment of its spatial and temporal extent observed during site visits.

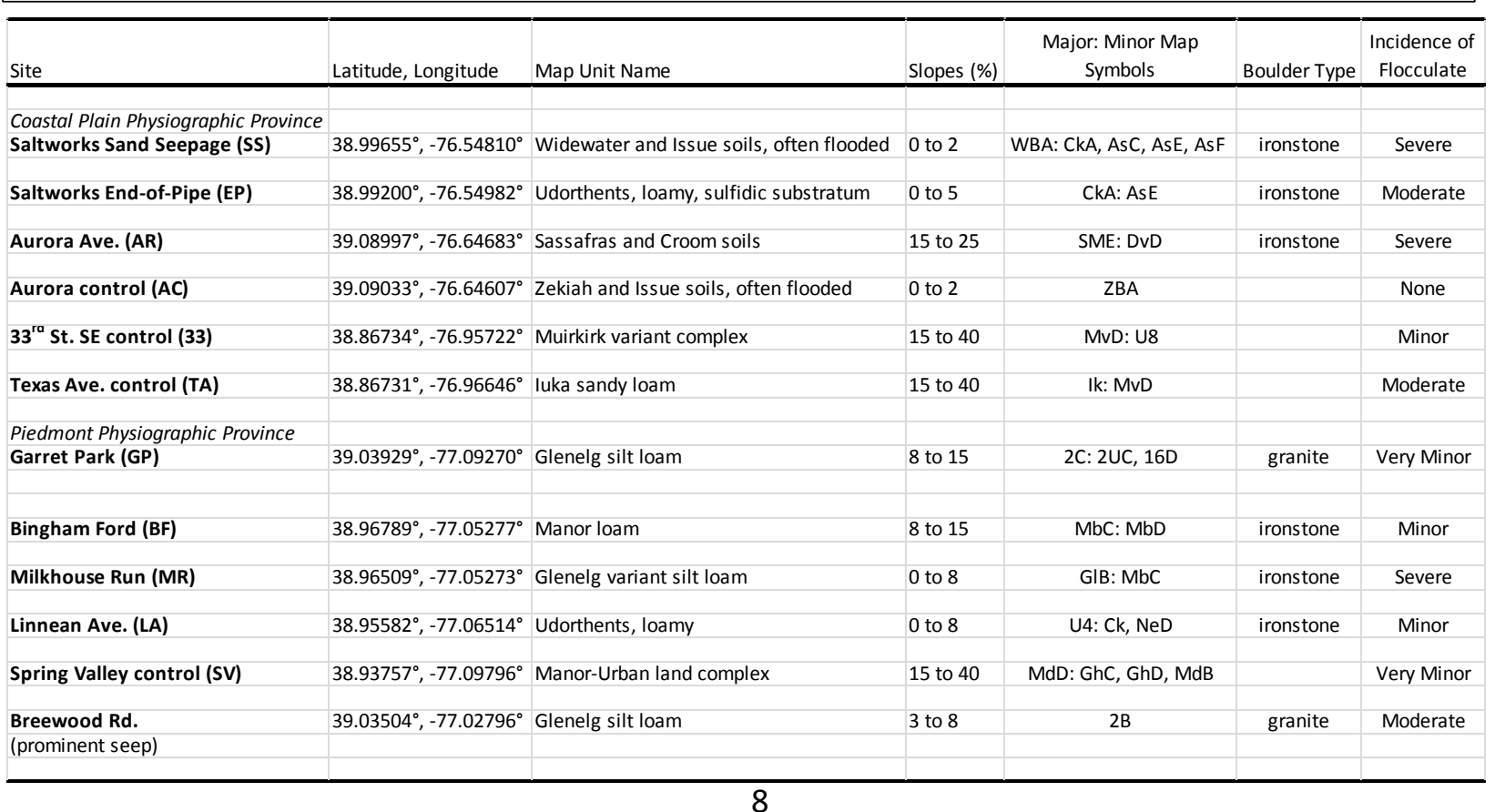


RSC construction

147 RSCs are commonly implemented in incised headwater channels or stormwater drainage

148 ditches using sand, wood-chips and riparian soils as bottom substrates (Brown et al. 2010).

149 Subsequently, boulder weirs oftentimes made from ironstone and silica-cobble riffles are

150 installed to create a series of step pools (Figure 3). Alternatively, granite boulders are used (i.e.,

151 GP site). Incised stream reaches or drainage ditches are thus transformed into a structure that

152 enhances water retention and percolation to the groundwater table, thereby decreasing the magnitude of peak stormwater runoff to receiving waters during precipitation events. Large

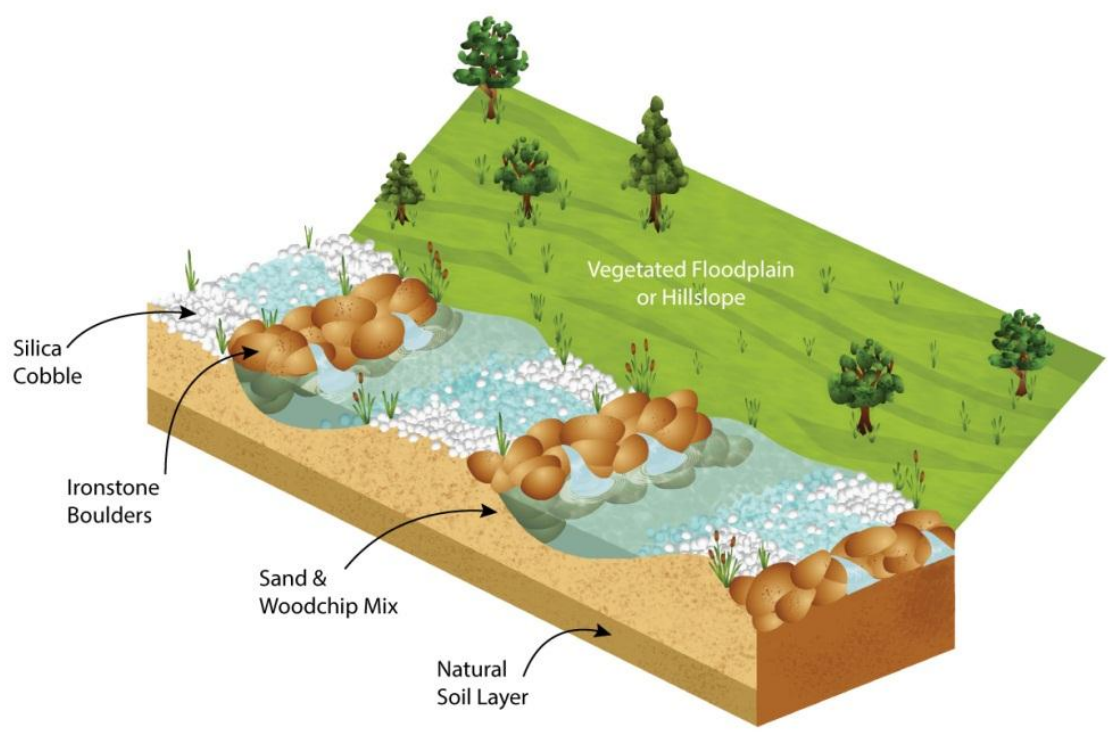

Figure 3: Schematic of RSC showing weirs constructed of silica cobble and ironstone boulders that separate step pools designed to decrease the magnitude of peak flow and partially retain stormwater runoff. 
154 woody debris such as tree trunks, branches, and root wads are often placed within the channel to 155 serve as habitat and as an additional organic carbon substrate. Generally, few trees are felled 156 during construction and the area disturbed by construction is not much wider than the incised 157 stream channel or drainage ditch.

158 The rationale for the use of ironstone in RSCs is that it may promote the water quality 159 conditions found in wetland environments (e.g., lower $\mathrm{pH}$ ) and help to establish native plant 160 communities while limiting invasive species. Ironstone deposits are natural in the Coastal Plain 161 and the stone occurs in a variety of forms including relatively dense and more loosely162 consolidated sandstone and conglomerate. All are relatively porous and at several sites the 163 surfaces of the boulders support mosses and small vascular plants without an overlying soil 164 layer. Ironstone is typically more expensive than alternative substrates such as granite, but some 165 stream restoration practitioners indicate that ironstone is easier to work with because it often 166 occurs in the form of large blocks that can be stacked on one another. By contrast, the use of $167 \mathrm{OM}$ in the fill material is meant to quickly re-establish detritus in streams that facilitate the re168 colonization of macroinvertebrates and the biogeochemical processes that are present in healthy 169 stream environments (i.e., denitrification, etc.). As mentioned previously, the amount of OM 170 integrated into the fill material is $<20 \%$ by volume (for example, MR and LA were $6 \%$ and $17 \%$, 171 respectively; note that the same \% of ironstone substrates were used). It is estimated that the OM 172 in the form of felled tree trunks, branches and root masses incorporated into the RSC ponding 173 basins can more than double this percentage, albeit much of this material likely decomposes 174 slowly. During the fall, leaves in residential communities transported in runoff or from 175 overlying forest canopy are commonly retained in RSC ponding basins and behind debris dams 176 for extended periods thereby contributing to elevated DOC levels in stream water. Leaves from 
177 the surrounding residential community were also incorporated into the RSC ponding basins to 178 provide additional carbon at the LA site.

\section{MATERIAL AND METHODS}

Analytical Methods

Stream and shallow groundwater concentrations of Fe, $\mathrm{Mn}$, nitrate $\left(\mathrm{NO}_{3}\right)$ and ammonium $\left(\mathrm{NH}_{4}\right)$, phosphate $\left(\mathrm{PO}_{4}\right)$, total dissolved $\mathrm{P}(\mathrm{TDP})$, DOC, chloride $(\mathrm{Cl})$, and sulfate $\left(\mathrm{SO}_{4}\right)$ were analyzed in this study. Most of our chemical analyses were done at the Nutrient Analytical Services Laboratory (NASL) at the Chesapeake Biological Laboratory (CBL). Methods and the detection limits for each analytical procedure used in this study can be found on the NASL webpage (http://nasl.cbl.umces.edu). Chemical constituents were analyzed using the following equipment: Fe and Mn - Ion Coupled Plasma-Optical Emission Spectrometer (ICP-OES), DOC - Shimadzu 5000A, all P fractions and $\mathrm{NH}_{4}$ - Aquakem 250. Nitrate, $\mathrm{Cl}$, and $\mathrm{SO}_{4}$ were analyzed using a Dionex ion chromatograph (IC 1000) in a separate lab at CBL. Subsamples of Fe flocculate and the materials used in RSC construction (pre-slurry) were sent to A\&L Eastern Laboratories (al-labs-eastern.com) to determine the total \% of Fe. The total \% of the metals cadmium, copper, Fe, lead and zinc were also determined on samples of dried flocculate at A\&L Eastern Laboratories. Other analyses done were particulate P (PP) on the dried flocculate and total dissolved nitrogen (TDN) for interstitial water, the latter using an Exeter Analytical, Inc. Model CE-440 Elemental Analyzer; particulate N and C were measured with a Perkin Elmer $2400 \mathrm{CHN}$ elemental analyzer.

\section{Precipitation, Stream and Groundwater Monitoring}

198 Pre- and post-construction stream and groundwater were monitored at the LA site to associated increases in baseflow expected in the post-construction period. The pre-construction sampling period was from January 2013 to May 2014, and the post-construction sampling period 
used in this study is from August 2014 through July 2015. Precipitation volume was collected using a tipping bucket rain gauge (Hobo RG3-M). Baseflow was collected approximately monthly, whereas stormflow was collected using Isco automated water samplers (Isco model 6712) approximately twice per season. Stormflow samples were generally collected every 20 minutes ( 3 aliquots per $1 \mathrm{~L}$ bottle) and volume-integrated using discharge measurements obtained from a $0.76 \mathrm{~m} \mathrm{H}$ flume where stage was measured using a pressure transducer (Onset HOBO water level logger; model U20-001-04-Ti) recording at 5-min intervals. In the postconstruction period, discharge was estimated using a rating curve for a culvert with a $1.04 \mathrm{~m}$ inner diameter.

Groundwater wells $(n=12)$ at the LA site were positioned at four separate transects of 2 to 4 wells each set perpendicular to the stream at approximately 0.6 to $1.5 \mathrm{~m}$ intervals from the stream bank. Each well was made of schedule 40 PVC with a $6.4 \mathrm{~cm}$ inner diameter and had a $0.254 \mathrm{~mm}$ slotted well screen at its base. Wells were generally about 2.4 to $3.6 \mathrm{~m}$ deep in order to continuously record groundwater fluctuations even in the late summer/ early fall when groundwater table levels were lowest. Well water was sampled using a PVC bailer, and each well was purged prior to sampling. Groundwater level fluctuations in each well were recorded using Hobo pressure transducers. A separate pressure transducer was located in the Isco fiberglass housing to record barometric data at the same time interval, and these data were subtracted from the stream stage and well data.

All other sites had one riparian and one in-stream (or in-pool) hyporheic monitoring well installed to depths ranging from about 1 to $2 \mathrm{~m}$. Water samples were collected 7 times from November 2013 to September 2014, and the two wells and stream water at each site were sampled 3 times per site per visit. The sites were sampled more intensively during June through 
225 mid-July 2014 (2-4 times each). Samples were collected during baseflow, no sooner than 24

226 hours after a precipitation event.

227 Water samples were kept on ice and filtered within 24 hours using polycarbonate filters $(0.4$

$228 \mu \mathrm{m}$ nominal pore size) into one $60 \mathrm{~mL}$ and two $30 \mathrm{~mL}$ subsamples. No DOC contamination was

229 apparent in filter blanks. The $30 \mathrm{~mL}$ subsamples were prepared and analyzed for Fe, $\mathrm{Mn}$, and

230 DOC, whereas the $60 \mathrm{~mL}$ subsamples were frozen and later analyzed for $\mathrm{PO}_{4}$ and $\mathrm{NH}_{4}$. The

231 remainder of the sample was analyzed for $\mathrm{NO}_{3}, \mathrm{Cl}$, and $\mathrm{SO}_{4}$. Rapid biological assessment

232 metrics were recorded once in July 2014, including trash rating, instream habitat, epifaunal

233 substrate, velocity/depth diversity, pool/glide/eddy quality, riffle/run quality, \% embeddedness

234 (i.e., how much the streambed is enveloped by flocculate), and \% shading (Stranko et al. 2014).

235 One longitudinal transect was conducted at the AR site. Water samples were collected from

236 flowing water at the riffles between the RSC pools. All samples were analyzed for nutrients, $\mathrm{Cl}$,

$237 \mathrm{SO}_{4}, \mathrm{DOC}$, and metals to determine if gradients exist within the RSC system and if FeOB thrive

238 at particular overlapping gradients, as can be seen in many natural bacterial communities

239 (Wimpenny 1989). Bivariate analyses, one-tailed t-tests, and analysis of variance (ANOVA)

240 were done with SigmaPlot 12.

241

242 Leaching Experiment

243 The effect of DOC on Fe and Mn dissolution from RSC construction materials and riparian

244 soils was tested using a modified method to study redox systems in sediments (Brannon et al.

245 1984). Substrate samples consisted of 9 soils excavated from riparian wells (installed using a

246 soil auger) and 5 different construction materials collected from RSC implementation sites.

247 Construction materials were quartz sand, mixed soil-OM fill (with activated carbon and wood- 
248 chips), ironstone conglomerate and sandstone, and granite. Substrates were air-dried for three 249 days prior to use and ground to pass a $2 \mathrm{~mm}$ sieve. Oven-dry equivalent masses were determined 250 by drying subsamples at $105^{\circ} \mathrm{C}$ for 9 hours and calculating the gravimetric water content of each 251 substrate. Substrate/water slurries were prepared (two 1:10 g/mL) for each material in question 252 by adding $405 \mathrm{~mL}$ of extractant solution to $40.5 \mathrm{~g}$ of substrate (oven-dry equivalent). The two 253 extractant solutions added were two different treatments applied to each substrate. One 254 extractant solution consisted of stream water collected from Woodland Branch in Calvert 255 County, MD (latitude, longitude: 38.4517899, -76.4785633); Fe flocculate was observed at this 256 site. The second extractant solution was collected from the same site on the same day but 257 prepared by placing $0.8 \mathrm{~kg}$ of wood chips and $0.7 \mathrm{~kg}$ of forest leaf litter (both collected from 258 RSC sites) into an HDPE container and filling to 5 gallons with the stream water. This mixture 259 was capped loosely and allowed to soak for 4 days in order to provide a high-DOC treatment in 260 order to ensure that DOC concentrations would not be rapidly exhausted during the experiment. 261 Both treatments were vacuum filtered through glass-fiber filters ( $0.7 \mu \mathrm{m}$ pore size $)$ before being 262 added to the substrates in order to reduce the influence of any particulate organic carbon.

263 Slurries were placed in $500 \mathrm{~mL}$ glass canning jars with screw-on metal lids and sparged with $\mathrm{N}_{2}$ 264 gas for 10 seconds to displace $\mathrm{O}_{2}$ and speed the development of anoxia. Three replicates were 265 prepared for each treatment and substrate for a total of 84 slurries. The slurries were incubated 266 in the dark at room temperature for 8 weeks, occasionally (i.e., several times before each 267 sampling) swirling them for 10 seconds to suspend the sediments.

268 The incubation jars were sampled after 1 and 8 weeks of leaching. A syringe was inserted 269 just below the surface of the solution to extract $100 \mathrm{~mL}$ of sample from each jar which was then 270 filtered through a polycarbonate filter $(0.4 \mu \mathrm{m}$ pore size $)$. The first replicate was filtered into 
271 three sets of $30 \mathrm{~mL}$ subsamples. The first set of these subsamples was stored in HDPE bottles

272 with $20 \mu \mathrm{L}$ of trace metal-grade nitric acid and refrigerated until analyses for Fe and $\mathrm{Mn}$. The

273 second set of subsamples were stored in $30 \mathrm{~mL}$ Teflon bottles and frozen until they were

274 analyzed for DOC, and the third set was frozen in HDPE bottles until analyzed for $\mathrm{NO}_{3}, \mathrm{Cl}$, and

$275 \mathrm{SO}_{4}$. The remaining two replicates were only analyzed for Fe and Mn. Statistical differences

276 among treatments were determined using the tests mentioned previously.

277

278

279

280

281

282

283

284

285

286

287

288

289

290

291

292

\section{Bacterial Mats}

Mat accumulation from FeOB was measured at 9 sites in July 2014 (not including LA and SV sites since there was no apparent mat formation in the pre-construction period), and longitudinally at the AR site, using a modified method originally intended to measure periphyton biomass (Steinman et al. 2006). Samples were taken from sites of maximum apparent mat accumulation in flowing water near where the monitoring wells were installed. Mat thickness and water depth to substrate were recorded. Samples were collected by lowering a $119 \mathrm{~cm}^{2}$ wooden frame into the mat and using a metal bar to scrape the substrate and vigorously agitate the contents inside the frame. A syringe was then used to extract $280 \mathrm{~mL}$ of the resultant slurry. The slurry was stored on ice until it could be returned to the laboratory and frozen. Samples were thawed two days later, agitated, and subsamples of known volume were filtered using preweighed, pre-combusted, glass-fiber filters $(0.7 \mu \mathrm{m}$ nominal pore size $)$. The filtered residue was dried at $105^{\circ} \mathrm{C}$ for 4 hours, weighed and then combusted at $450^{\circ} \mathrm{C}$ for 4 hours. The combusted material was then weighed to determine ash-free dry weight (AFDW) and total volatile solids (TVS). The \% Fe flocculate by weight was calculated as: (AFDW/dried flocculate)*(100). 
Thick mats of flocculate (Figures $4 \mathrm{a} \& \mathrm{~b}$ ) were sampled at the SS and MR sites to analyze

interstitial water and dried material. These sites were selected because they commonly have

collected in 1-L Isco bottles and refrigerated for 48 hours at which time aliquots were filtered to
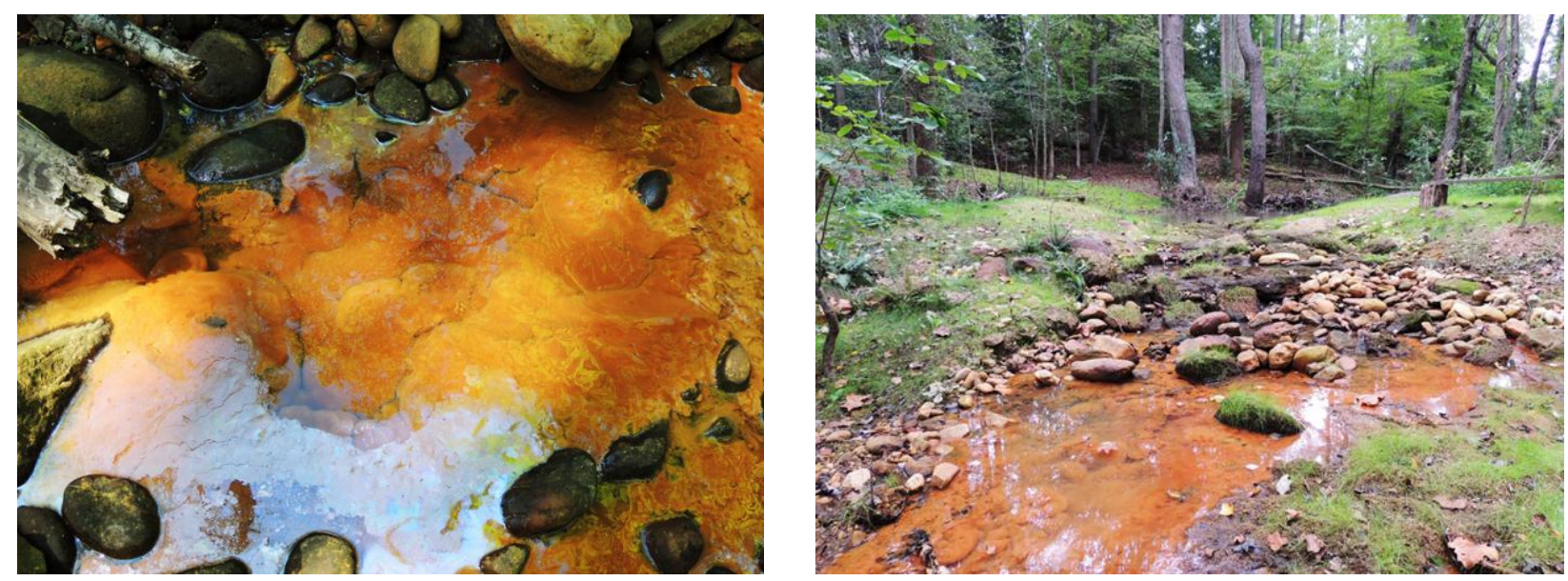

Figures $4 \mathrm{a} \& \mathrm{~b}$ : $3 \mathrm{a}$ - left photo) Flocculate from $\mathrm{FeOB}$ at the lower reaches of the Milkhouse Run (MR) RSC site. The white surface film in the foreground is commonly associated with flocculate production. $3 \mathrm{~b}$ - right photo). Abundant flocculate from $\mathrm{FeOB}$ downstream of a weir constructed of ironstone substrates at the Saltworks Creek Sand Seepage (SS) RSC site. Iron flocculate collected from these sites was dried and analyzed for various constituents.

obtain interstitial water (as described previously) and the remaining flocculate dried in Pyrex

trays for several days. A portion of the dried material was sent to A\&L Laboratories for total metals analysis (i.e., $\mathrm{Cu}, \mathrm{Cd}, \mathrm{Fe}, \mathrm{Pb}$, and $\mathrm{Zn}$ ), and to NASL for PP analysis. The interstitial water was analyzed for various solutes using the same techniques described previously. 


\section{RESULTS}

Stream and Groundwater Monitoring

A pre- and post-construction comparison at the LA site indicated that RSC implementation

307 increased Fe and DOC concentrations in both stream water and groundwater near the stream

308 channel. Sampling began in January of 2013 and continued for 1 year after the RSC was

309 implemented in June - July 2014 (i.e., post-construction period from August 2014 through July

310 2015). Volume-weighted mean (VWM) concentrations of Fe at the LA site increased more than

311 an order of magnitude from 0.04 to $0.40 \mathrm{mg} / \mathrm{L}$ and 0.09 to $1.01 \mathrm{mg} / \mathrm{L}$ from the pre- to the post-

312 construction period in baseflow and stormflow, respectively. By contrast, VWM concentrations

313 in the pre- and post-construction periods at the SV control site were only slightly higher in

314 baseflow (0.008 and $0.03 \mathrm{mg} / \mathrm{L}$, respectively) and stormflow (0.08 and $0.09 \mathrm{mg} / \mathrm{L}$, respectively).

315 The EPA criterion for Fe concentrations in natural freshwater systems is $1 \mathrm{mg} / \mathrm{L}$

316 (www.epa.gov/wqc/national-recommended-water-quality-criteria-aquatic-life-criteria-table).

317 Annual precipitation volume at the LA site in the pre-construction period of May 1, 2013

318 through April 30, 2014 was about 6\% lower than in the post-construction period of August 1, 3192014 to July 31, 2015 (1167 mm vs $1248 \mathrm{~mm}$, respectively). 
The network of well transects in the LA catchment (Figure 2) showed a rapid increase in the

water table during construction due to several rain events $>10 \mathrm{~mm}$ that occurred during the

beginning of this period. The average increase in the water table was about $0.76 \mathrm{~m}$ (Figure 5), and individual wells ranged from 0.15 to $1.2 \mathrm{~m}$. By contrast, the water table decreased in the control catchment (SV) during the LA site recharge period by 0.3 to $1 \mathrm{~m}$, with an average of about $0.5 \mathrm{~m}$.

Concentrations of Fe and DOC in the groundwater wells were monitored in the pre- and post-

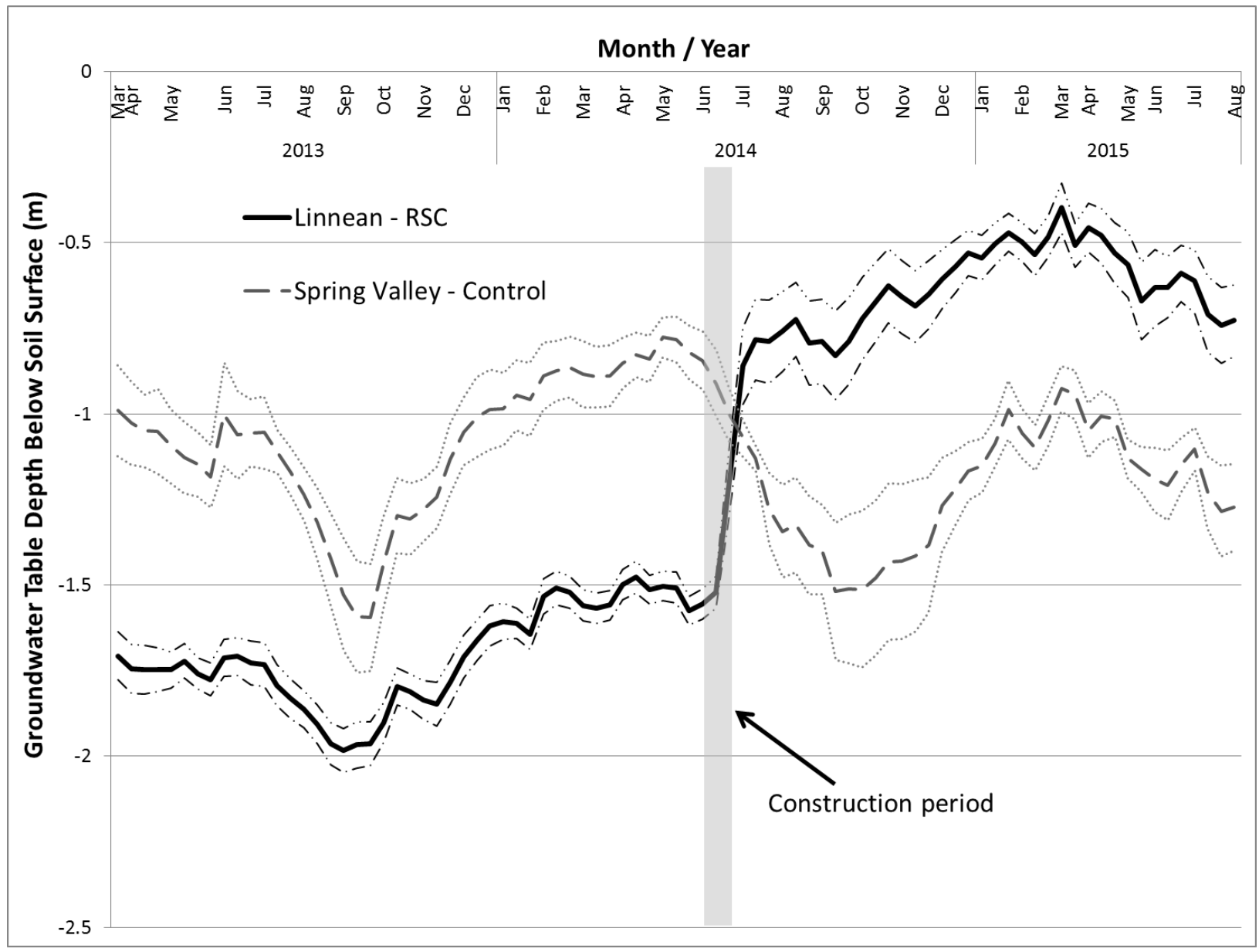

Figure 5: Groundwater level below soil surface (m) \pm SE at the Linnean Ave. (LA) RSC and Spring Valley (SV) control sites indicating how RSC construction at LA substantially increased the water table via groundwater recharge. Well data were collected at 5-min intervals and the graph represents 10-day minimum groundwater levels. 


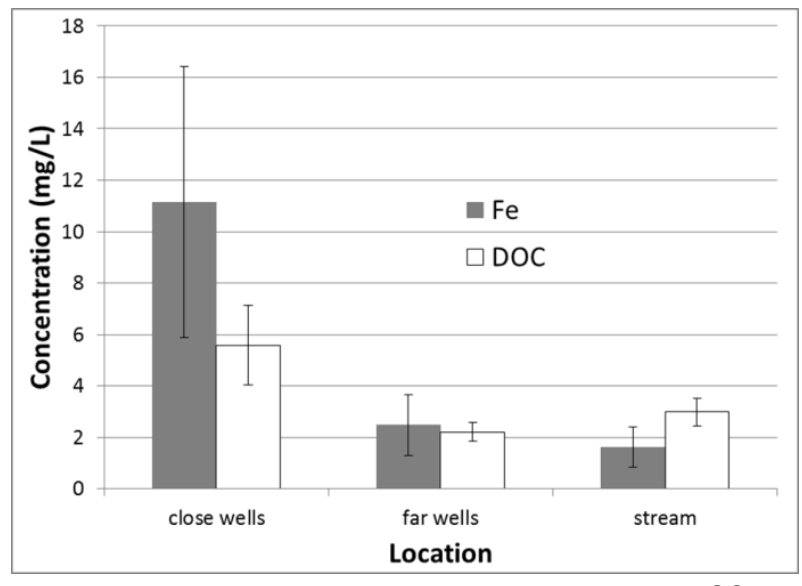

331
Figure 6: Mean concentrations $( \pm \mathrm{SE})$ of DOC and $\mathrm{Fe}$ in groundwater wells located at distances of $<1 \mathrm{~m}$ (close) and $\geq 1 \mathrm{~m}$ (far) from the RSC construction area of the LA site.

construction periods. Both Fe and DOC concentrations were higher in the wells located in closer proximity $(<1 \mathrm{~m})$ to the LA RSC construction area than in stream water and the

wells located $>1 \mathrm{~m}$ from the stream (Figure 6).

An inter-site comparison of stream water, and riparian and hyporheic well water in the 12

RSC and control sites indicate that streamwater Fe concentrations were generally much lower than those in groundwater (Figure 7). Differences in Fe concentrations between RSC and control sites for the three types of water monitored were insignificant in each category in the Coastal

Plain physiographic province (i.e., stream water, and riparian and hyporheic well water), whereas

Figure 7: Mean concentrations of Fe in riparian and hyporheic wells, and stream water in the Coastal Plain (CP) and Piedmont $(\mathrm{P})$ physiographic provinces. Streamwater concentrations are a factor of 10 times higher than actual values to facilitate comparisons among study sites.

those in the Piedmont were significantly different. Using an unpaired, one-tailed t-test,

Fe concentrations between Piedmont RSCs

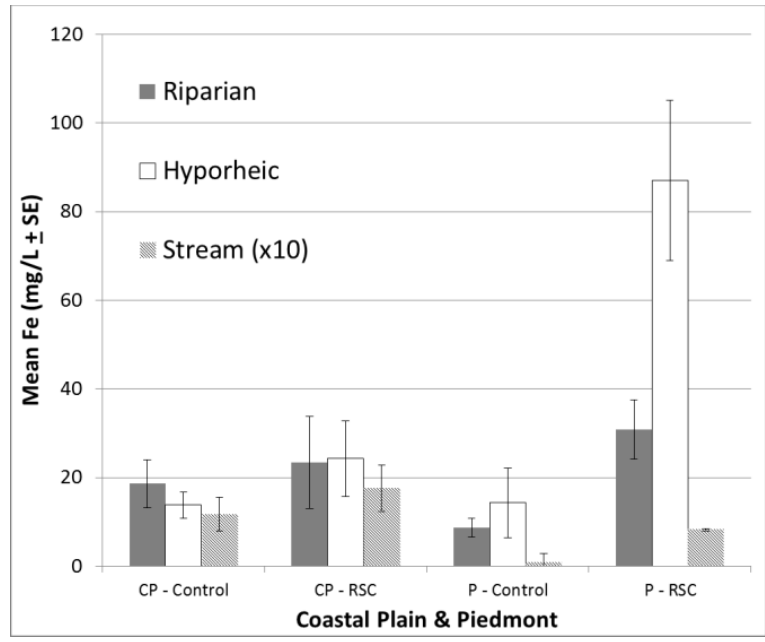

(MR, BF, GP) and control sites (LA - pre construction, SV) were significantly higher in the RSCs $(\mathrm{p}<0.05)$. The significant difference improved with GP removed from this test and only ironstone-containing RSCs were compared with the control sites $(\mathrm{p}<0.01)$. Concentrations of DOC and Fe at MR were as high as 28 and $210 \mathrm{mg} / \mathrm{L}$ in hyporheic water. Other constituents 


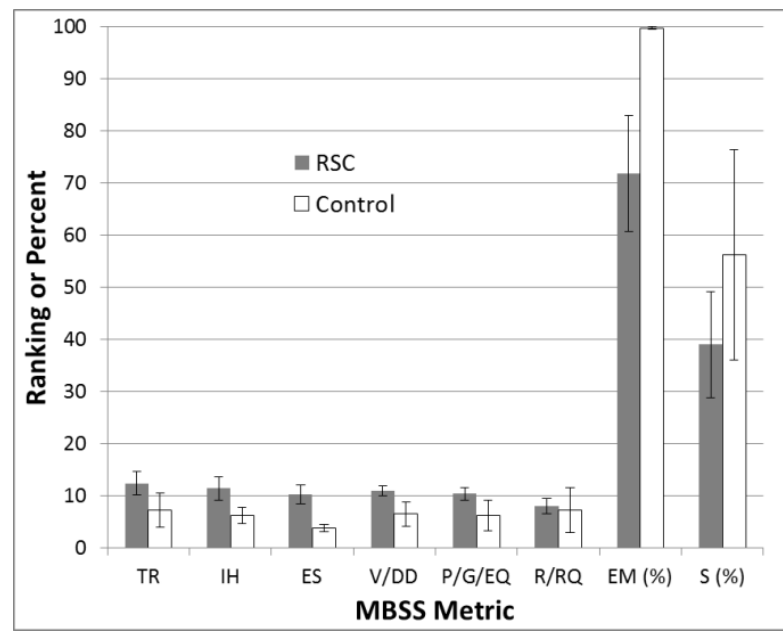

Figure 8: Mean values $( \pm \mathrm{SE})$ of physical habitat metrics for RSC and control sites. Data were obtained using Maryland Biological Stream Survey (MBSS) methods. Acronyms are the following: Trash Rating (TR), Instream Habitat (IH), Epifaunal Substrate (ES), Velocity/Depth Diversity (VDD), Pool/Glide/Eddy Quality (PGEQ), Riffle/ Run Quality (RRQ), Embeddedness (EM), and Shading (S). lower (i.e., worse) on embeddedness $(\mathrm{p}<0.05$;
353

Figure 8). The RSC sites scored higher (i.e., better) than control sites on velocity/depth diversity and pool/glide/eddy quality, but significant differences were moderate $(0.05<\mathrm{p} \leq 0.1)$.

Differences in riffle/run quality or shading were insignificant.

Fe flocculate accumulation did not differ significantly in terms of dry mass per unit area between RSCs and control streams, even when site GP (granitic construction material) was removed from the calculation. However, when a two-sample t-test was run between the 5 RSCs constructed with ironstone and the 4 sites without ironstone added (i.e., 3 control sites and GP), the increase in AFDM of the flocculate was moderately significant $(\mathrm{p}=0.07)$. The percentage of volatile solids (\%VS) of the Fe flocculate was also significantly higher at RSCs than the control sites $(\mathrm{p}=0.001)$. 


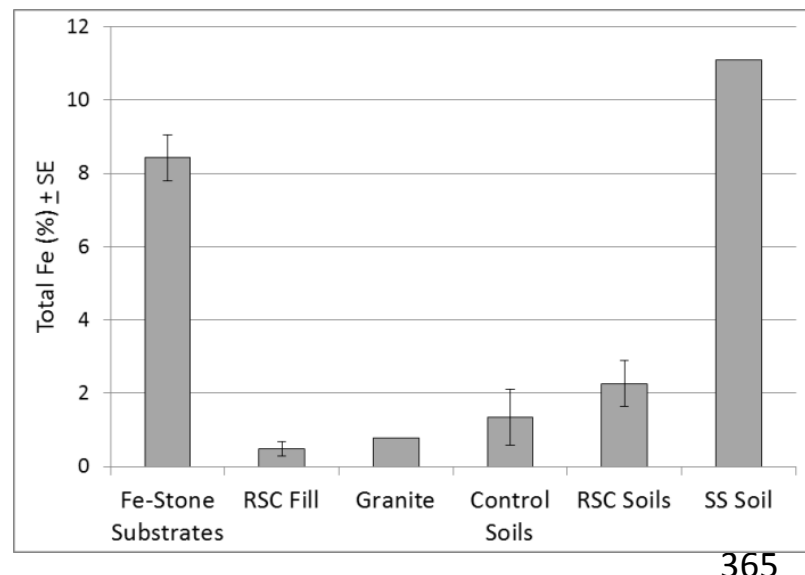

Figure 9: Mean \% Fe values $( \pm \mathrm{SE})$ derived from the soils and construction materials extracted from the study sites. The SS site is shown independently from other RSC sites because of its high \% Fe value.

\section{Leaching Experiment}

Total Fe (\%) was generally higher in the

ironstone varieties than the soils extracted from riparian and hyporheic wells, and the fill

materials. Granite and RSC fill were the lowest and soils from the SS site were the highest in Fe

of the substrates and Fe or DOC concentrations in the pure streamwater treatment $\left(\mathrm{r}^{2}=0.06\right.$ and without a DOC addition was sampled from each jar after 1 and 8 weeks. The samples with a concentrations across the replicates and the effect of the DOC addition was significant ( $\mathrm{n}=14$,

$375 \mathrm{p}<0.05)$. Only a small increase in concentration

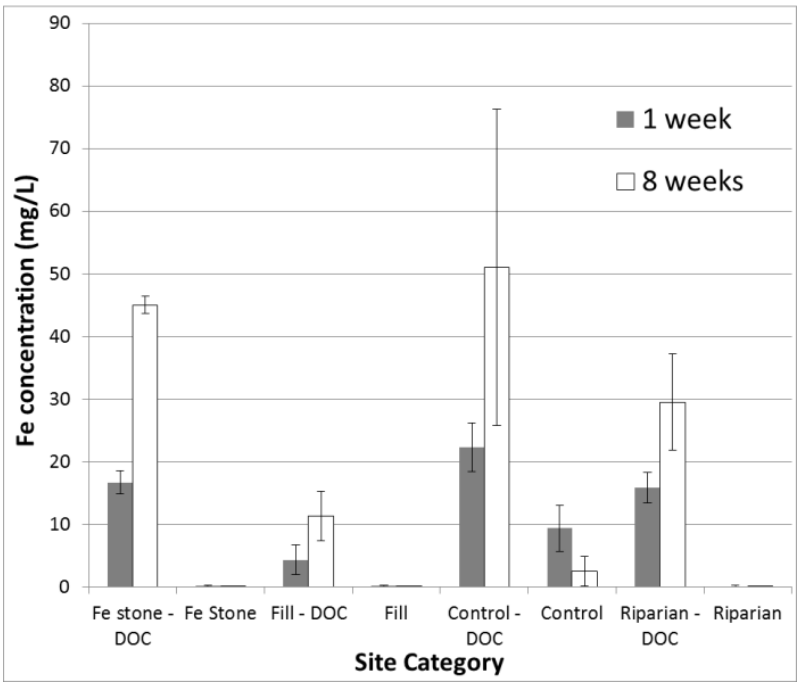
(maximum of $2.5 \mathrm{mg} / \mathrm{L}$ ) was observed for $\mathrm{Mn}$

Figure 10: Mean concentrations of Fe $( \pm \mathrm{SE})$ from soils and construction materials used at the RSC sites after 1 and 8 weeks of leaching. Soils and construction materials were leached in filtered stream water at room temperature in the dark after sparging with $\mathrm{N}_{2}$. Treatments with DOC additions are labeled accordingly. 
377 after one week of leaching $(n=14, p<0.05)$; samples collected after 8 weeks were not analyzed

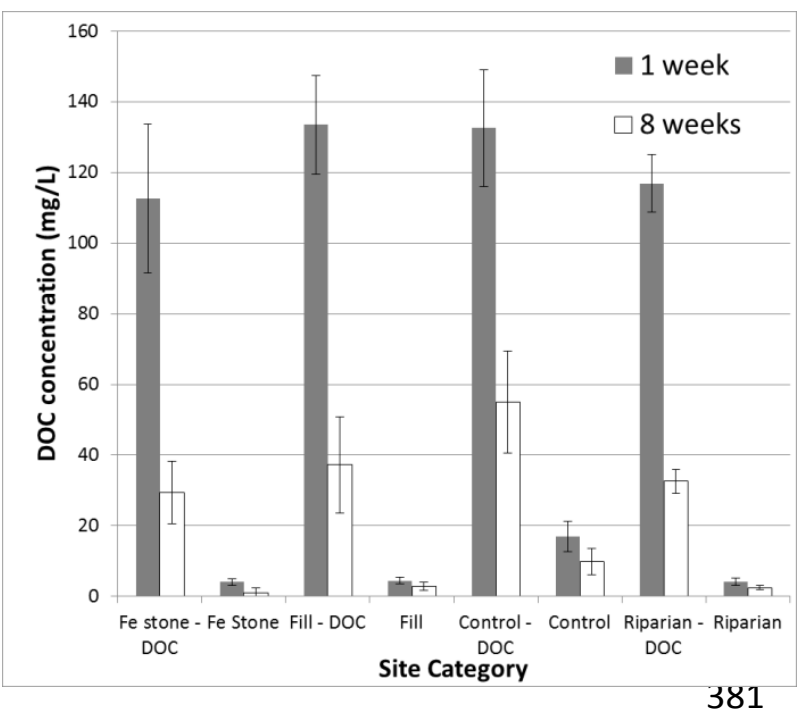

Figure 11: Mean concentrations of DOC $( \pm \mathrm{SE})$ from soils and construction materials used at the RSC sites after 1 and 8 weeks of leaching. Soils and construction materials were leached in filtered stream water at room temperature in the dark after sparging with $\mathrm{N}_{2}$. Treatments with DOC additions are labeled accordingly.

\section{Longitudinal transect}

Solute concentrations in water samples collected from the longitudinal transect conducted in July 2014 at the AR site both increased and decreased from up- to down-stream sampling stations 1 to 8 (Figure 12). Because $\mathrm{Cl}$ is considered a conservative solute and concentrations gradually decreased along the transect, this decrease was attributed in part to the lateral influx of more Cl-dilute groundwater. The effect

of groundwater dilution on solute

concentrations along the transect was

Figure 12: Solute concentrations modified by a $\mathrm{Cl}$ dilution factor to partially remove the effects of dilution on trends; resulting values are unitless. Stations 1 to 8 (up- to down-stream transect) at the AR site were sampled in July 2014.

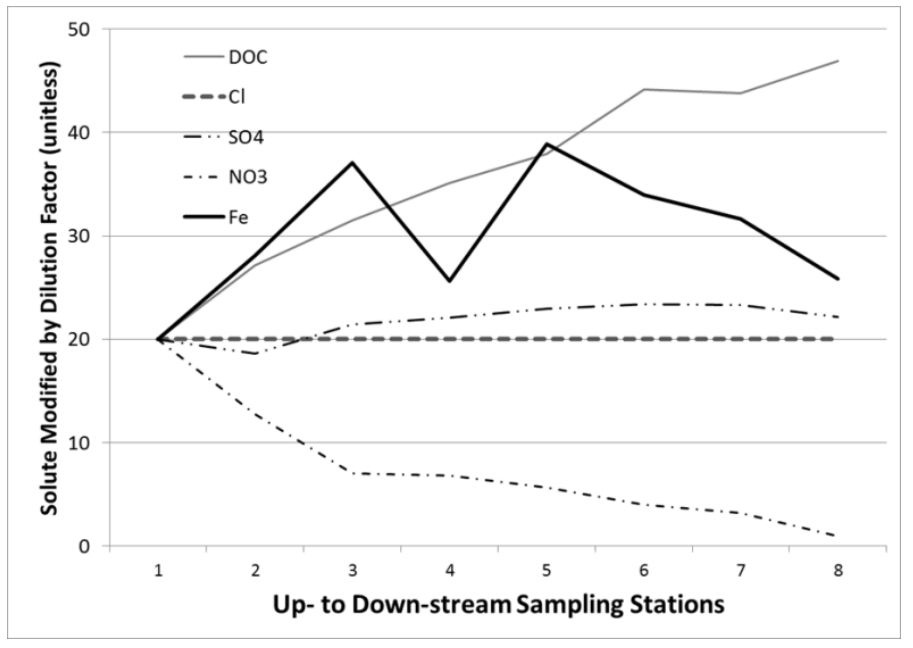


390 partially removed by calculating a dilution factor for each station based on $\mathrm{Cl}$ (Williams et al.

391 2004). Applying the dilution factor creates an invariant unitless value for $\mathrm{Cl}$ to which all other

392 solutes can be compared. For example, the trend for $\mathrm{SO}_{4}$ was similar to $\mathrm{Cl}$, whereas that of DOC

393 increased steadily throughout transect. Similarly, Fe concentrations increased relative to $\mathrm{Cl}$, but

394 exhibited more variability compared to DOC. By contrast, $\mathrm{NO}_{3}$ steadily decreased relative to $\mathrm{Cl}$

395 along the transect.

Throughout the AR transect, Fe flocculate showed a trend of increasing dry mass

397 (represented as \% weight of flocculate in Figure 13) and AFDM from the up- to down-stream

398 sampling stations. The \%VS of the Fe flocculate

399 oscillated from $75 \%$ to $30 \%$ (Wessel and

400 Williams 2014).

Figure 13: Fe flocculate by weight shown as the $\%$ of total dry matter at the sampling stations of the AR longitudinal transect.

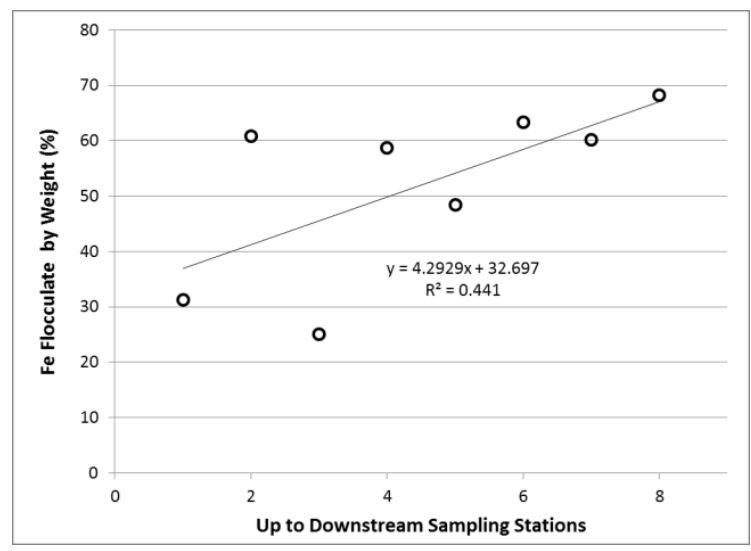

401

Chemical composition of bacterial mats

Thick mats of Fe flocculate from FeOB were collected at the MR and SS sites in September 2014 to determine the chemical composition of both interstitial water and dried flocculate. The composition of the dried material was analyzed for total Fe (\%), particulate phosphorus (\%), and

407 other constituents (Table 2). Total Fe ranged from 37 to $42 \%$, and PP from 0.2 to $0.6 \%$. The 
410 concentrations of the interstitial water were generally higher than those in stream water for Fe,

411 DOC, and the $\mathrm{N}$ fractions, not including $\mathrm{NH}_{4}$.

Table 2: Measurements from Fe flocculate samples - \%P, \% Fe, and interstitial water.

Criteria concentrations in natural freshwaters for $\mathrm{Cd}, \mathrm{Cu}, \mathrm{Pb}$ and $\mathrm{Zn}$ are 0.72, NA, 2.5 and $120 \mathrm{ug} / \mathrm{L}$, respectively (www.epa.gov/wqc/national-recommended-water-quality-criteriaaquatic-life-criteria-table).

\begin{tabular}{|c|c|c|c|c|c|c|c|c|c|c|}
\hline \multirow{2}{*}{\begin{tabular}{l}
\multicolumn{1}{c}{ Dried } \\
Flocculate \\
Site
\end{tabular}} & \multirow[b]{2}{*}{$\mathrm{Fe}$} & \multirow[b]{2}{*}{ PP } & \multirow{2}{*}{ volatiles } & \multirow[b]{2}{*}{ PN } & \multirow{2}{*}{$\mathrm{PC}$} & \multicolumn{4}{|c|}{$\begin{array}{l}\text { Total Trace Metal } \\
-(\mathrm{mg} / \mathrm{kg})\end{array}$} & \\
\hline & & & & & & $\mathrm{Cu}$ & $\mathrm{Zn}$ & $\mathrm{Cd}$ & $\mathrm{Pb}$ & \\
\hline $\mathrm{MR}$ & 41.5 & 0.58 & 17.0 & 0.75 & 5.47 & $<5$ & 66 & 5 & 19 & \\
\hline SS & 36.8 & 0.24 & 18.3 & 0.50 & 5.13 & 11 & 89 & 6 & 23 & \\
\hline $\begin{array}{l}\text { Interstitial } \\
\text { Fluid }\end{array}$ & \multicolumn{10}{|c|}{ Concentration } \\
\hline Site & $\mathrm{Fe}$ & $\mathrm{DOC}$ & $\mathrm{PO}_{4}$ & TDP & $\mathrm{NH}_{4}$ & $\mathrm{NO}_{3}-\mathrm{N}$ & TDN & DON & $\mathrm{Cl}$ & $\mathrm{SO}_{4}$ \\
\hline $\mathrm{MR}$ & 15.8 & 10.4 & 0.001 & 0.006 & 0.37 & $<0.01$ & 1.28 & 0.91 & 159.5 & 8.6 \\
\hline SS & 1.2 & 5.9 & 0.001 & 0.009 & 0.16 & 0.02 & 0.57 & 0.39 & 25.6 & 3.2 \\
\hline
\end{tabular}

\section{DISCUSSION}

Sources of DOC and Fe in RSCs

417 It is well known that anaerobic microbes use alternative electron acceptors to maintain

418 metabolic activity (Emerson 2000, Emerson et al. 2010, Melton et al. 2014). For example, as

419 OM decomposes, FeRM use the DOC derived from this OM as substrate to reduce Fe derived

420 from Fe-bearing minerals (Brannon et al. 1984, Lovely 1986). In RSCs, because relatively fresh

421 OM (i.e., wood chips, leaves, tree trunks and branches) is added and boulder weirs retain stream

422 water thereby raising the groundwater table (Figure 5), submerged OM leaches DOC into

423 solution, analogous to the preparation of the DOC treatment in our leaching experiments.

424 Oxygen is quickly exhausted in water-saturated soils and FeRM reduce Fe to continue utilizing

425 the DOC that remains in solution. Groundwater flowing through riparian soils and hyporheic

426 zones where construction materials are located in the plume of concentrated DOC leachates from 
427 OM either embedded into RSCs or naturally occurring then emerges as stream bank and 428 hyporheic seepage thereby contributing reduced Fe to stream water.

429 The inverse relationship of increasing Fe and decreasing DOC concentrations over time confirm that these processes occurred in our leaching experiments. Moreover, these experiments

431 indicate that the elevated Fe concentrations in the stream water and groundwater wells at RSC

432 sites are derived from Fe minerals not only in riparian soils, but also in the ironstone varieties 433 used as construction materials. Every substrate leached more Fe under anoxic conditions with 434 added DOC, but ironstone conglomerate and sandstone leached more than most of the other 435 substrates tested (Wessel and Williams 2014). By contrast, quartz sand and the GP boulders 436 leached relatively small amounts of Fe into solution compared to other substrates.

437 No relationship was observed between the Fe content of a substrate and the amount of Fe 438 leached to solution, likely because naturally occurring Fe minerals occur in a variety of 439 crystalline forms. This difference accounts for some Fe minerals being less available to 440 microbial reduction thereby slowing the rate at which they leach (Lovley 2000). Furthermore, 441 the surface-area-to-volume ratio of each substrate would have had some influence on the amount 442 of Fe leached into solution. Thus, ironstone substrates (i.e., sand and conglomerate) that have 443 smaller surface areas by weight than riparian soils, would likely have leached more Fe if their 444 surface areas were larger (i.e., similar to the surface area of fine-textured riparian soils).

445 As in our leaching experiments, the surface area of ironstone substrates used in prominent 446 flowpath areas of RSCs should have a large impact on the amount of Fe leaching that occurs. 447 Large, relatively pure ironstone boulders that have low surface-area-to-volume ratios likely leach 448 lower amounts of Fe into stream water than areas that are largely composed of ironstone sand 449 and smaller, loosely-consolidated ironstone substrates. Indeed, MR and SS are sites that have a 
450 high incidence of flocculate below weirs that appear to have a larger proportion of loosely-

451 consolidated ironstone rock and sand than at upstream weirs of the RSCs that use larger, more

452 consolidated ironstone boulders. Some of the loosely-consolidated ironstone used in these weirs

453 can be broken apart by hand and their surfaces easily gouged with a knife. At the SS site (note

454 that the name "sand seepage - SS" was given to this site because of the large amount of loosely-

455 consolidated ironstone material used in the construction of the weirs), Fe concentrations in

456 stream water increased from 0.6 to $5.6 \mathrm{mg} / \mathrm{L}$ immediately above and below the weir composed of

457 this loosely-consolidated ironstone, and the reach downstream of the weir commonly had very

458 dense mats of flocculate (Figure 4b). As mentioned previously, concentrations of Fe in

459 hyporheic water at the MR site were as high as $210 \mathrm{mg} / \mathrm{L}$, and this was located in the stream

460 reach that utilized smaller sized and loosely-consolidated ironstone substrates.

461 We observed relatively small riparian areas at several study sites where Fe flocculate forms

462 at groundwater seeps that appear during wetter-than-average periods. The flocculate at these

463 sites typically leaves an Fe-rich residue as the groundwater table subsides and the seeps dry out.

464 However, observations from a RSC site located in the Piedmont not sampled as part of this study

465 (i.e., Breewood Rd.) are of interest because although only low-Fe content substrates were used

466 (i.e., granite boulders and low-Fe content sand), moderate amounts of flocculate developed in the

467 stream channel. The flocculate at this site resulted in large part because of a hydrological

468 connection that was made between the stream and a large deposit of OM in the upper soil

469 horizons (i.e., litter, $\mathrm{O}$ and $\mathrm{A}$ horizons) that became saturated, likely because of recharge of the

470 groundwater table that occurred after construction. This area was several meters from the RSC

471 reach and exhibited Fe flocculate in tannic, organic-rich water. Water trickling from the

472 saturated seep area to the stream created blooms of FeOB in several ponding basins months after 
473 construction. The following year the RSC reach in proximity to the seep exhibited some dense

474 mats of Fe flocculate, and Fe staining of the silica cobble and light coatings of Fe flocculate on

475 strands of filamentous algae in the riffles downstream of the seep area. The RSC reach above the

476 seep area remained completely clear of Fe flocculate and had no Fe staining of the silica cobble.

477 We surmise that this hydrological connection was formed with recharge of the groundwater table

478 after construction and that the influence of this seep is therefore largely dependent on the height

479 of the water table. If so, then the influence of the seep on flocculate conditions in the RSC will

480 likely diminish as the groundwater table subsides throughout the summer and early fall, as

481 measured at the LA site (Figure 5).

482

$483 \quad$ Fe flocculate in an intensively-monitored RSC

$484 \quad$ Flocculate associated with FeOB was never observed at the intensively-monitored LA site in 485 the pre-construction period. However, rust-colored stream water in the ponding basins was 486 observed in the fall (2014) and winter (2015) of the post-construction period and, by the summer 487 of 2015, thick mats of FeOB were observed at several locations during periods with very little 488 storm activity. The appearance of Fe flocculate in the post- construction period coincided with 489 an increase in Fe concentrations in baseflow and stormflow of 39 to 515 and 93 to $333 \mathrm{ug} / \mathrm{L}$, 490 respectively. Despite a 7\% decrease in total runoff compared to the pre-construction period, 491 higher Fe concentrations in the post-construction period resulted in a 13-, 3- and 5-fold increase 492 in the annual area yields of Fe in baseflow, stormflow, and total flow, respectively,. Area yields 493 of Fe for the pre- and post-construction periods were 466 and 2,112 $\mathrm{g} \mathrm{ha}^{-1} \mathrm{yr}^{-1}$, respectively. 494 Concentrations of DOC in stream water in the pre-construction period are unavailable, but had a 
495 significant $(\mathrm{p}<0.05)$ increasing trend in baseflow from $3 \mathrm{mg} / \mathrm{L}$ at the beginning of the post512 through the fall). construction period to $5 \mathrm{mg} / \mathrm{L}$ toward the end of this period.

Iron flocculate manifested in many of the RSC ponding basins that were filled with leaves from the overlying tree canopy in the fall, and the flocculate appeared more as colloidal material or accumulations of small particles $<5 \mathrm{~mm}$ in diameter in rust-colored water rather than as the mats normally observed in the growing season. Because Fe flocculate can also occur spontaneously through the oxidation of reduced Fe in stream water (Emerson et al. 2010), we speculate that the formation of this flocculate could be more of an abiotic process than a biotically-mediated process by $\mathrm{FeOB}$ because of its configuration as colloids and particulates, not as mats. Moreover, particulate flocculate was sometimes observed in the ponding basins during periods when streamwater temperatures were $<5^{\circ} \mathrm{C}$ (Williams and Filoso 2016). Bacterial growth is limited during very cold periods since metabolic activity at low temperatures ceases, with $5^{\circ} \mathrm{C}$ commonly being referred to as biologic zero (Rabenhorst 2005). Fleming et al. (2014) similarly observed that there were no bacterial mats of flocculate in a ME stream during the winter, and $\mathrm{FeOB}$ exhibited a clear seasonal succession coupled with niche separation between the helical stalk-forming Gallionellales (i.e., Gallionella ferruginea, which is apparent in the early spring) and tubular sheath-forming Leptothrix ochracea (prevalent in the late spring

The increase of Fe and DOC concentrations in stream water coincided with an increase in the concentrations of these solutes in well water, and these increases are more pronounced in wells located $<1 \mathrm{~m}$ from the RSC construction area than those located further away (Figure 6). Thus, groundwater data confirm that the plume of more concentrated DOC groundwater originating from the $\mathrm{OM}$ embedded into the RSC construction materials is restricted to the area in close 
518 proximity to the stream itself. Because the results of our leaching experiments indicate that Fe 519 concentrations in groundwater are enhanced in the presence of DOC, the wells located further 520 away from the RSC that are uninfluenced by DOC leachates remained low in Fe concentrations.

521 Hydrological pathways involving lateral flow to water through or over surface soil layers

522 often have relatively high concentrations of DOC (Kaplan and Newbold 1993). By contrast,

523 water flowpaths that pass slowly though lower soil layers usually have low DOC concentrations

524 because these soil layers ( $\mathrm{B}$ and $\mathrm{C}$ horizons) often contain $\mathrm{Fe}$ and aluminum oxides that

525 effectively sorb and immobilize DOC (McDowell and Wood 1984). Given that increases in Fe

526 and DOC concentrations did not occur in the wells $>1 \mathrm{~m}$ away from the RSC construction area,

527 this suggests that in most instances a rise in the groundwater table that does not penetrate

528 organic-rich upper soils horizons will unlikely contribute much leached Fe to groundwater and 529 the stream.

530 Consequently, at the LA site there is little Fe mobilized from existing soil stocks that 531 contributed to the increase in Fe concentrations in the stream other than from those soils 532 influenced by the plume of more concentrated DOC water originating from the OM embedded 533 into the RSC construction area itself. Thus, once groundwater levels increased after the RSC 534 construction, this water inundated the OM built into the RSC and began to leach concentrated 535 DOC. As in our leaching experiments, this DOC likely promoted the leaching of Fe from both 536 the soils and construction materials in the RSC area thereby contributing to the development of 537 Fe flocculate at various locations throughout the structure. 
Solute dynamics in a RSC transect

The analysis of samples collected in a longitudinal transect at the AR RSC study site indicates that several key solutes exhibit very different concentration dynamics as they flow through this structure. Partially removing the effects of streamwater dilution by using a $\mathrm{Cl}$ modification factor (Williams et al. 2004) shows that DOC consistently increases along the transect relative to $\mathrm{Cl}$, likely because of residual $\mathrm{OM}$ buried in the $\mathrm{RSC}$ and natural sources. Even though some DOC is removed as Fe is reduced and leached into solution, as observed in our leaching experiments that used a finite amount of DOC in a closed environment, the OM in proximity to this RSC is constantly leaching DOC to the stream. Concentrations of DOC likely increased throughout the transect because the downstream sampling sites had proportionally larger influence from DOC in groundwater than the upstream sites.

Iron concentrations increased relative to the $\mathrm{Cl}$ baseline, albeit with higher variability than with DOC. Decreases in Fe concentration at several locations along the transect suggest that communities of FeOB were effectively scavenging Fe from stream water. As indicated previously, large and dense mats from FeOB were often observed in the water trickling through ironstone boulder weirs (Figure 13). Thus some of the reduced Fe in stream water flowing through the riffles of some boulder weirs was being utilized by FeOB to create flocculate.

Decreases in $\mathrm{NO}_{3}$ concentrations are commonly associated with uptake (e.g., by algae and periphyton that convert $\mathrm{NO}_{3}$ to organic $\mathrm{N}$ ) or loss (e.g., denitrification in riparian soils and hyporheic zones). It has also been hypothesized that $\mathrm{NO}_{3}$ removal is associated with the oxidation of $\mathrm{Fe}$, where denitrifying bacteria utilize reduced $\mathrm{Fe}$ as an electron donor (Burgin and Hamilton 2007). At the LA site, there was considerably more uptake and/or loss of $\mathrm{NO}_{3}$ after RSC construction compared to before. The annual area yield of $\mathrm{NO}_{3}$ for the pre-construction 
563 period was significantly higher $(\mathrm{p}<0.05)$ than in the post-construction period $(4.9$ versus $0.9 \mathrm{~kg}$

$564 \mathrm{ha}^{-1} \mathrm{yr}^{-1}$, respectively), although part of this difference is a result of a decrease in total runoff in 565 the post-construction period $(7 \%)$. The decreasing trend in $\mathrm{NO}_{3}$ concentration modified by the 566 dilution factor along the AR site transect suggests that $\mathrm{N}$ uptake and loss are also prevalent in 567 this RSC.

568

569

570

571

572

573

574 575 large part from Fe flocculate, suggests that many aquatic macroinvertebrates and other species

\section{Effects of RSC implementation on health-based stream habitat metrics and metals}

One of the main objectives of restoring degraded stream and stormwater drainage ditches is to improve water quality and physical habitat characteristics in order to promote the recovery of the biota and their ecological functions. Because habitat and substrate diversity are designed into RSCs, it is not surprising that several habitat metrics rate significantly higher (i.e., better) than the control sites (Figure 8). However, the significantly lower embeddedness rating (worse), in may be restricted from colonizing new substrate (Wellnitz et al. 1994). Nevertheless, frogs and

577 tadpoles were abundant at RSC sites, as were snails, which were commonly found on the surface

578 FeOB mats. Fish were only observed at several sites (i.e., AR, AC and Breewood Rd.), but their 579 occurrence is likely more regulated by other factors. For example, discontinuities in the stream 580 network might prohibit fish migration to RSC reaches. Adult dragonflies were common at RSC 581 sites, though larvae were only observed at the LA and GP sites, which exhibited minor to very 582 minor amounts of Fe flocculate (Table 1).

583 Mats of FeOB have been shown to accumulate arsenic and may also accumulate other toxic 584 metals (Morin et al. 2003). Indeed, the trace metal content of the dried flocculate material 585 collected at two of our sites indicate that there is a concentrating effect of these constituents in 
flocculate that are much higher than criteria levels for natural fresh waters (Table 2). Although RSCs are accumulating heavy metals in these bacterial mats, the concentrating effect is not likely biologically harmful because periodic flushing of the system by precipitation events removes established mats of FeOB and dilutes accumulated metals in stormflow runoff.

\section{Factors regulating the development of Fe flocculate}

Iron concentrations in the streams of Coastal Plain RSCs were not significantly different than those of the control streams. By contrast, Fe concentrations in the Piedmont RSCs constructed using ironstone were significantly higher than those of the controls (Figure 7). Only relatively small areas with surface coatings of Fe flocculate were observed at our Piedmont control sites over the period of study. Similarly, the flocculate observed at Coastal Plain control sites commonly occurred in small areas or as a ubiquitous light coating on stream sediments (once at the TA site). However, observations from a number of other sites in the MD and DC areas suggest that the flocculate associated with FeOB is relatively ubiquitous in Coastal Plain streams compared to those in the Piedmont. In both physiographic provinces, there tends to be relatively more and denser flocculate in RSCs than in control streams, particularly during summer and lowflow periods between storms. Thus, streamwater temperature (Fleming et al. 2014) and discharge are two important factors regulating the development of flocculate from $\mathrm{FeOB}$.

While Fe flocculate was observed at both control and RSC sites, there were striking differences in terms of its total abundance, composition and distribution among sites. For example, Fe flocculate at RSC sites tended to have higher percentages of volatile material than the control sites (Wessel and Williams 2014), and the densest accumulations were commonly observed in the water trickling through ironstone boulder weirs and rock riffles. Moreover, most 
609 of the flocculate that does occur is relatively localized and likely depends on certain hydrological 610 conditions. For example, there is a tendency for dense flocculate to develop at the ponding

611 basins and riffles located in more downstream areas than upstream, probably because there is

612 more constant groundwater saturation of soils in these areas and therefore an environment that is 613 more conducive to the leaching of DOC from OM, which enhances the leaching of reduced Fe.

614 The growth of FeOB is also regulated by sources of Fe derived from riparian zones and their 615 soil composition can vary substantially among sites (e.g., SS site, Figure 9). Moreover, it is 616 likely that the disturbance of riparian soils during construction contribute to higher Fe 617 concentrations in stream and well water until the system stabilizes. We also observed at the 618 Breewood site that establishing hydrological connections between RSC reaches and natural 619 stocks of OM in the floodplain is another mechanism whereby DOC and reduced Fe inputs to the 620 stream can enhance flocculate.

621 It is important to recognize that not all RSCs develop what can be considered a serious 622 flocculate problem. For example, our most intensively monitored RSC study site (i.e., LA) has 623 experienced occasional blooms of FeOB in the ponding basins and developed flocculate mats at 624 several locations, but none constitute what could be considered as serious stream impairments. 625 Nevertheless, despite the limited amount of flocculate observed at the LA site and the variability 626 in flocculate among the RSC and control sites in both physiographic provinces, our data show 627 that dense accumulations of Fe flocculate can be an unintended consequence of RSC 628 implementation. This consequence is not surprising given the increases in labile Fe and DOC 629 concentrations that occur in stream water after RSC construction and the riffles and ponding 630 basins of RSCs that create ideal low-flow environments where FeOB can thrive. Our leaching 631 experiments confirm that the mineralization of Fe from $\mathrm{Fe}$-containing substrates is enhanced by 
632 DOC in anoxic environments. Because these conditions are created in RSCs and ironstone 633 substrates have some of the highest \% Fe values of any construction material or riparian soil at

634 our study sites (Figure 9), these substrates have the potential to contribute relatively high

635 concentrations of Fe to stream water, particularly in some Piedmont streams (such as those in 636 this study) where background concentrations are commonly below the lower limit needed for

637 FeOB to grow and proliferate $(<0.1 \mathrm{mg} / \mathrm{L})$. At concentrations of Fe higher than this threshold, 638 DO concentrations $>0.3 \mathrm{mg} / \mathrm{L}$ are needed for Fe bacteria to carry out oxidation (Andrews et al. 639 2012).

640 These findings support our contention that the particles and dense mats of Fe flocculate 641 sometimes observed at several of our RSC study sites are in large part regulated by DOC inputs 642 originating from OM incorporated into the RSCs in conjunction with naturally occurring OM 643 stocks that leach Fe from construction materials with relatively high Fe content (i.e., ironstone 644 substrates) and natural soils. Accordingly, localized soil characteristics (i.e., Fe and OM content) 645 and catchment topography should be evaluated when deciding how much and where to utilize 646 OM, as well as what types of construction materials to use and their position in the restoration 647 reach.

\section{CONCLUSIONS}

650 Results of this study indicate that the implementation of RSCs in degraded urban streams can

651 decrease nutrient and sediment loads and improve many physical habitat metrics. However, 652 although flocculate was apparent in both RSC and control streams, more pervasive 653 accumulations were commonly observed in RSCs in the late spring through early fall. The 654 formation of Fe flocculate varies spatially and temporally, but the sometimes complete 
655 embeddedness of benthic substrate in these areas prohibits their use by many aquatic organisms

656 (e.g., benthic macroinvertebrates) and may result in a range of other limitations that affect

657 normal biogeochemical processes (e.g., denitrification in hyporheic zones) and decrease RSC

658 performance (i.e., a reduction in nutrient loads) and sustainability.

659 Based on a combination of data, extensive observations, and information available from other

660 studies, there are several regulating factors that contribute to excessive flocculate formation in

661 RSCs. Conditions that promote the growth of FeOB include low-flow environments, warmer

662 temperatures, and concentrations of $\mathrm{Fe}$ and $\mathrm{DO}>0.1$ and $0.3 \mathrm{mg} / \mathrm{L}$, respectively. The regulating

663 factors that can contribute to the development of flocculate under these conditions include Fe

664 leached from construction materials with relatively high Fe content (e.g., loosely-consolidated

665 ironstone substrates sand, small rocks and boulders) located in areas influenced by DOC derived

666 from OM embedded in RSCs and OM deposits in riparian zones or floodplains that become

667 linked hydrologically to the stream by groundwater recharge. Hence, in instances where

668 relatively low quantities of OM are used in construction and hydrological connections with

669 natural deposits of OM in the catchment are avoided, using relatively high Fe content

670 construction materials such as ironstone will not leach much Fe into groundwater that can

671 potentially augment the production of Fe flocculate. Alternatively, in cases where hydrological

672 connections are made with the stream to natural seeps or deposits of OM in or in close proximity

673 to the RSC reach, then it is likely that the use of construction materials with relatively high Fe

674 content will enhance the development of Fe flocculate. In such instances, the use of ironstone

675 substrates should be avoided, particularly sand and small rocks derived from ironstone deposits

676 and ironstone boulders that are loosely consolidated and more subject to higher rates of

677 biogeochemical weathering. 
678 Although RSCs work well to serve some of their intended functions (i.e., create stream 679 habitat, decrease the magnitude of stormwater runoff and erosion, and recharge groundwater), 680 dense accumulations of flocculate from $\mathrm{FeOB}$ can degrade stream habitat and aesthetics.

681 Because flocculate is regulated in part by inherent soil characteristics, the type and quantity of 682 construction materials used, and the unique configuration and hydrology of each RSC, utilizing 683 this knowledge during construction should help to alleviate a range of possible impairments 684 stemming from Fe flocculate.

685

686 ACKNOWLEDGEMENTS

687 Support for this project was provided by the District Department of Energy and the 688 Environment (grant \# 12G-12-NFWF-UMCES/WPD-2), Maryland Sea Grant (REU program), 689 NOAA (grant \# NA10OAR4310221), and the National Science Foundation (REU 690 student/mentor travel award). We thank Steve Saari and Joe Berg for assistance with site 691 selection, as well as Peter May and Delvin Fanning for constructive input on the REU project.

692 Rosemary Ury and Jake Kames provided lab and field assistance. 693 694 


\section{REFERENCES}

Andrews, S., Norton, I., Salunkhe, A.S., Goodluck, H., Aly, W.S.M., Mourad-Agha, H., Cornelis, P., 2013. Chapter 7, Control of Iron Metabolism in Bacteria. In: L. Banci (Ed.). Metallomics and the Cell. Met. Ions Life Sci. Springer. 12:203-239.

Berg, J., Underwood, K., 2007. Constructed weirs and pools for safe, non-erosive conveyance of stormwater runoff: An example of regenerative design. Ecological Society of America Annual Meeting Abstracts.

Bowen, R., 2012. Regenerative Step Pool Conveyance (SPSC) Design Guidelines. Anne Arundel County Government Department of Public Works Bureau of Engineering.

Brannon, J.M., Gunnison, D., Smart, R.M., Chen, R.L., 1984. Effects of added organic matter on iron and manganese redox systems in sediment. Geomicrobiology Journal 3: 319-341.

Brown, T., Berg, J., Underwood. K., 2010. Regenerative Stormwater Conveyance: An Innovative Approach to Meet a Range of Stormwater Management and Ecological Goals, p. 3399-3413. World Environmental and Water Resources Congress 2010. American Society of Civil Engineers.

Brown, K., 2000. Urban stream restoration practices: an initial assessment. The Center for Watershed Protection. Ellicott City, MD.

Burgin, A.J., Hamilton, S.K., 2007. Have we overemphasized the role of denitrification in aquatic ecosystems? A review of nitrate removal pathways. Frontiers in Ecology and the Environment 5(2), 89-96.

Doyle, M.W., Harbor, J.M., Rich, C.F., Spacie, A., 2000. Examining the effects of urbanization on streams using indicators of geomorphic stability. Physical Geography 21:155-181. 
717 Emerson, D., Fleming, E.J., McBeth, J.M., 2010. Iron-Oxidizing Bacteria: An Environmental 718 and Genomic Perspective. Annu. Rev. Microbiol. 64:561-83

719 Emerson, D., 2000. Microbial Oxidation of Fe(II) and Mn(II) at Circumneutral pH, p. 31-52. In 720 D. R. Lovley [ed.], Environmental Microbe-Metal Interactions. ASM Press.

721 Emerson, D., Revsbech, N.P., 1994a. Investigation of an Iron-Oxidizing Microbial Mat

722 Community Located Near Aarhus, Denmark - Field Studies. Applied and Environmental $723 \quad$ Microbiology 60: 4022-4031.

724 ---. 1994b. Investigation of an Iron-Oxidizing Microbial Mat Community Located Near Aarhus, 725 Denmark - Laboratory Studies. Applied and Environmental Microbiology 60: 4032-4038. 726 Federal Interagency Stream Restoration Working Group - FISRWG. 1998. Stream Corridor 727 Restoration: Principles, Processes, and Practices. GPO Item No. 0120-A; SuDocs No. A 728 729 57.6/2:EN3/PT.653; Federal Interagency Stream Restoration Working Group, ISBN 0934213-59-3.

Filoso, S., Palmer, M.A., 2011. Assessing stream restoration effectiveness at reducing nitrogen export to downstream waters. Ecol. Appl. 21:1989-2006.

Fleming, E.J., Cetinic, I., Chan, C.S., King, D.W., Emerson, D., 2014. Ecological succession among iron-oxidizing bacteria. International Society for Microbial Ecology 8:804-815.

735 Ephemeroptera). Freshwater Biology 27:79-84

736 Ghiorse, W.C., 1986. Biology of Leptothrix, Gallionella, and Crenothrix; Relationship to 737 Plugging, p. 97-108. In D.R. Cullimore [ed.], International Symposium on Biofouled 738 Aquifers: Prevention and Restoration. American Water Resources Association. 
739 Grimm, N.B., Sheibley, R.W., Crenshaw, C.L., Dahm, C.N., Roach, W.J., Zeglin, L.H., 2005. N 740 retention and transformation in urban streams. J. N. Amer. Benthol. Soc. 24:626-642.

741 Hayer, C., Holcomb, B.M., Chipps, S.R., 2013. Associations between iron concentration and 742 productivity in montane streams of the Black Hills, South Dakota. The Prairie Naturalist $743 \quad 45: 68-76$.

744 Johnson, D. B., Hallberg, K.B., Hedrich, S., 2014. Uncovering a microbial enigma: Isolation and 745 characterization of the streamer-generating, iron-oxidizing, acidophilic bacterium "Ferrovum 746 myxofaciens". Applied and Environmental Microbiology 80:672-680.

747 Kaplan, L.A., Newbold, J.D., 1993. Sources and biogeochemistry of terrestrial dissolved organic 748 carbon entering streams. pp. 139 - 165 in T. E. Ford, ed. Aquatic microbiology: an ecological $749 \quad$ approach. Blackwell Scientific.

750 Likens, G.E., Bormann, F.H., 1995. Biogeochemistry of a Forested Ecosystem. Springer-Verlag, $751 \quad$ New York, 159 p.

752 Likens, G.E., Bormann, F.H., Johnson, N.M., Fisher, D.W., Pierce, R.S., 1970. Effects of forest 753 cutting and herbicide treatments on nutrient budgets in the Hubbard Brook watershed 754 ecosystem. Ecol. Monogr. 40:23-47.

755 Lovley, D.R., 2000. Fe(III) and Mn(IV) Reduction, p. 3-30. In D. R. Lovley [ed.], Environmental $756 \quad$ Microbe-Metal Interactions. ASM Press.

757 Lovely, D.R., 1986. Organic matter mineralization with the reduction of ferric iron: A review. $758 \quad$ Geomicrobiology Journal 5:375-399.

759 Melton, E.D., Swanner, E.D., Behrens, S., Schmidt, C., Kappler, A., 2014. The interplay of 760 microbially mediated and abiotic reactions in the biogeochemical Fe cycle. Nature Reviews $761 \quad$ Microbiology 12:797-808. 
ECOLENG-D-15-01350R1

Revised 6-24-16

762 Meyer, J.L., Paul, M.J., Taulbee, W.K., 2005. Stream ecosystem function in urbanizing

763 landscapes. J. N. Amer. Benthol. Soc. 24:602-612.

McDowell, W.H.,Wood, T., 1984. Podzolization: soil processes control dissolved organic carbon concentrations in stream water. Soil Science 137:23-32.

Morin, G., Juillot, F., Casiot, C., Bruneel, O., Personné, J.C., Elbaz-Poulichet, F., Leblanc, M., Ildefonse, P., Calas, G., 2003. Bacterial formation of tooeleite and mixed arsenic(III) or arsenic(V)-iron(III) gels in the Carnoules acid mine drainage, France. A XANES, XRD, and SEM study. Environ. Sci. Technol. 37:1705-1712.

Palmer, M.A., Filoso, S., Fanelli, R.M., 2014. From ecosystems to ecosystem services: Stream restoration as ecological engineering. Ecological Engineering 65:62-70.

Poff, N.L., Zimmerman, J.K., 2010. Ecological responses to altered flow regimes: a literature review to inform the science and management of environmental flows. Freshwater Biol. 55:194-205.

Rabenhorst, M., 2005. Biologic zero: A soil temperature concept. Wetlands. 25:616-621.

Rasmussen, J., Lindegaard, C., 1988. Effects of iron compounds on macroinvertebrate communities in a Danish lowland river system. Wat. Res. 22:1101-1108.

Robbins, E.I., 1998. Sites in the Virginia-Washington, D.C.-Maryland metro area to observe or collect bacteria that precipitate iron and manganese oxides. Open-File Report.

Robbins, E.I., Norden, A.W., 1994. Microbial oxidation of iron and manganese in wetlands and creeks of Maryland, Virginia, Delaware, and Washington, D.C., p. 1154-1159. In S.-H. Chiang [ed.], Coal-Energy and the Environment: Eleventh Annual International Pittsburgh Coal Conference. 
784 Schieber, J., Glamoclija, M., 2007. Microbial mats built by iron bacteria: a modern example

785

786

787

788

789

790

791

792

793

794

795

796

797

798

799

800

801

802

803

804

from southern Indiana, p. 233-244. In J. Schieber et al. [eds.], Atlas of microbial mat features preserved within the clastic rock record. Elsevier.

Selvakumar, A., O'Connor, T.P., Struck, S.D., 2010. Role of stream restoration on improving benthic macroinvertebrates and in-stream water quality in an urban watershed: case study. J. Environ. Eng. 136:127-139.

Singewald Jr., J.T., 1911. Dissertation: The Iron Ores of Maryland with an Account of the Iron Industry. Johns Hopkins University.

Steinman, A.D., Lamberti, G.A., Leavitt, P.R., 2006. Biomass and pigments of benthic algae, p. 357-379. In F. R. Hauer and G. A. Lamberti [eds.], Methods in Stream Ecology. Academic Press.

Stranko, S., Boward, D., Kilian, J., Becker, A., Ashton, M., Southerland, M., Franks, B., Harbold, W., Cessna, J., 2014. Maryland Biological Stream Survey: Round Four Field Sampling Manual. Maryland Department of Natural Resources.

Sweeney, B.W., Bott, T.L., Jackson, J.K., Kaplan, L.A., Newbold, J.D., Standley, L.J., Horwitz, R.J., 2004. Riparian deforestation, stream narrowing, and loss of stream ecosystem services. Proc. Natl. Acad. Sci. U.S.A. 101:14132-14137.

Vietz, G., Stewardson, M., Walsh, C., Fletcher, T., 2012. Another reason urban streams are stuffed: geomorphic history, challenges and opportunities. In Proceedings of the $6^{\text {th }}$ Australian Stream Management Conference, Managing for Extremes, 6-8; Grove, J.R., Rutherford, I.D., Eds.; River Basin Management Society: Canberra, Australia, 2012; pp 1-7. 
Walsh, C., Roy, A., Feminella, J., Cottingham, P., Groffman, P., Morgan, R., 2005. The urban stream syndrome: current knowledge and the search for a cure. Journal of the North American Benthological Society 24:706-723.

Wellnitz, T.A., Grief, K.A., Sheldonm, S.P., 1994. Response of macroinvertebrates to blooms of iron-depositing bacteria. Hydrobiologia 281:1-17.

Wenger, S.J., Roy, A.H., Jackson, C.R., Bernhardt, E.S., Carter, T.L., Filoso, S., Gibson, C.A., Hession, W.C., Kaushal, S.S., Marti, E., Meyer, J.L., Palmer, M.A., Paul, M.J., Purcell, A.H., Ramirez, A., Rosemond, A.D., Schofield, K.A., Sudduth, E.B., Walsh, C.J., 2009. Twentysix key research questions in urban stream ecology: an assessment of the state of the science. J. N. Amer. Benthol. Soc. 28:1080-1098.

Wessel, B., Williams, M., 2014. Factors responsible for the development of Fe flocculate in streams with and without regenerative stormwater conveyance (RSC) structures. Research Experience for Undergraduates. Final report.

Williams, M., Filoso, S., 2016. Report for the Linnean RSC and Spring Valley Control Catchments, Pre- and Post-Construction Periods, November $27^{\text {th }}, 2012$ to November $30^{\text {th }}$, 2015. Final Report to the District Department of Energy and the Environment, 22 p.

Williams, M., Hopkinson, C., Vallino, J., Rastetter, E., 2005. Relationships of land use and streamwater solute concentrations in the Ipswich River basin, northeastern Massachusetts. Water, Air, and Soil Poll. 161:55-74.

Williams, M., Hopkinson, C., Rastetter, E., Vallino, J., 2004. N budgets and aquatic uptake in the Ipswich River basin, northeastern Massachusetts. Wat. Resour. Res. Vol. 40, W11201, doi:10.1029/2004WR003172. 
827 Williams, M.R., Melack, J.M., 1997a. Effects of prescribed burning and drought on the 828 streamwater chemistry of mixed-conifer forest streams in the Sierra Nevada, California.

$829 \quad$ Biogeochemistry 39:225-253

830 ---. 1997b. Solute export from forested and partially deforested catchments in the central

831 Amazon. Biogeochemistry 38:67-102

832 Wimpenny, J., 1989. Laboratory model systems for the experimental investigation of gradient 833 communities, p. 366-383. In Y. Cohen and E. Rosenberg [eds.], Microbial Mats:

834 Physiological Ecology of Benthic Microbial Communities. American Society for 835 Microbiology. 